\title{
Wind Turbine Generator System Power Performance Test Report for the Mariah Windspire 1-kW Wind Turbine
}

A. Huskey, A. Bowen, and D. Jager

Technical Report NREL/TP-500-46192

December 2009 


\title{
Wind Turbine Generator System
} Power Performance Test Report for the

\section{Mariah Windspire 1-kW Wind Turbine}

Conducted for

\author{
National Renewable Energy Laboratory \\ 1617 Cole Blvd. \\ Golden, CO 80401 \\ Conducted by \\ National Wind Technology Center \\ National Renewable Energy Laboratory \\ 1617 Cole Boulevard \\ Golden, Colorado 80401
}

Arlinda Huskey, Amy Bowen, Dave Jager

10 June 2009 


\section{Notice}

This report was prepared by the National Renewable Energy Laboratory (NREL), operated for the United States Department of Energy (DOE) by the Alliance for Sustainable Energy, LLC (Alliance), as an account of work sponsored by the United States government. The test results documented in this report define the characteristics of the test article as configured and under the conditions tested.

THIS REPORT IS PROVIDED "AS IS" AND NEITHER THE GOVERNMENT, ALLIANCE, NREL NOR ANY OF THEIR EMPLOYEES, MAKES ANY WARRANTY, EXPRESS OR IMPLIED, INCLUDING THE WARRANTIES OF MERCHANTABILITY AND FITNESS FOR A PARTICULAR PURPOSE, OR ASSUMES ANY LEGAL LIABILITY OR RESPONSIBILITY FOR THE ACCURACY, COMPLETENESS, OR USEFULNESS OF ANY SUCH INFORMATION DISCLOSED IN THE REPORT, OR OF ANY APPARATUS, PRODUCT, OR PROCESS DISCLOSED, OR REPRESENTS THAT ITS USE WOULD NOT INFRINGE PRIVATELY OWNED RIGHTS.

Neither Alliance nor the U. S. Government shall be liable for special, consequential or incidental damages. Reference herein to any specific commercial product, process, or service by trade name, trademark, manufacturer, or otherwise does not necessarily constitute or imply its endorsement, recommendation, or favoring by the United States government or any agency thereof. The views and opinions of the authors expressed herein do not necessarily state or reflect those of the United States government or any agency thereof or Alliance.

NREL is a DOE Laboratory, and as an adjunct of the United States government, cannot certify wind turbines. The information in this report is limited to NREL's knowledge and understanding as of this date.

NREL is accredited by the American Association for Laboratory Accreditation (A2LA) and the results shown in this test report have been determined in accordance with the NREL's terms of accreditation unless stated otherwise in the report.

This report shall not be reproduced, except in full, without the written approval of Alliance or successor operator of NREL.

Approval By:

$$
\text { Arlinda Huskey, NREL Test Engineer Date }
$$

Review By: 


\section{Contents}

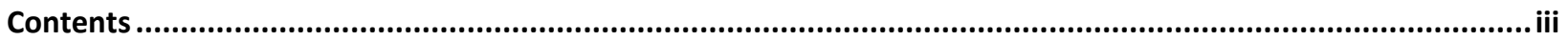

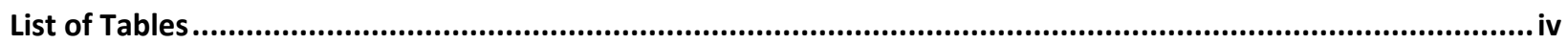

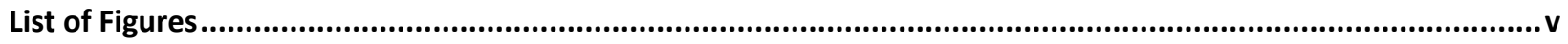

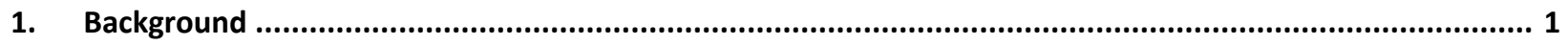

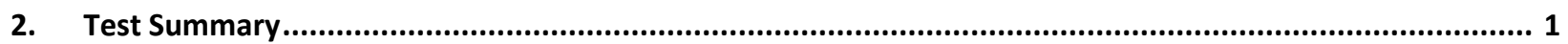

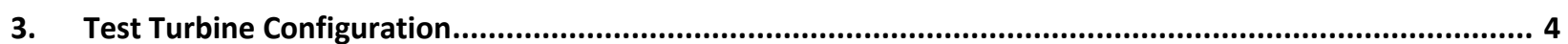

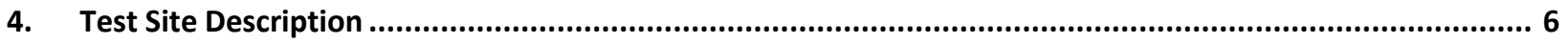

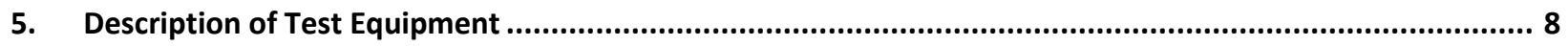

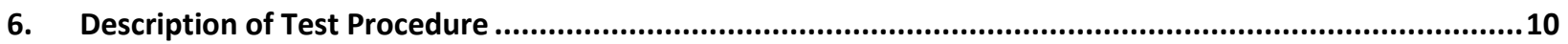

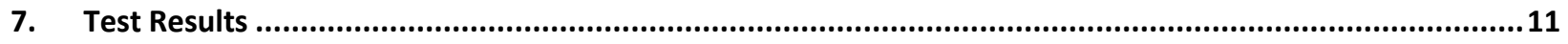

7.1. Results of Power Performance Test for the Normal Configuration.........................................................11

7.1.1. Tabular Results for Normal Power Production ............................................................................11

7.1.2. Graphical Results for Normal Power Production .....................................................................15

7.2. Results of Power Performance Test for Optimized Power Production ..................................................21

7.2.1. Tabular Results for Optimized Power Production .........................................................................21

7.2.2. Graphical Results for Power-Optimized Configuration..............................................................25

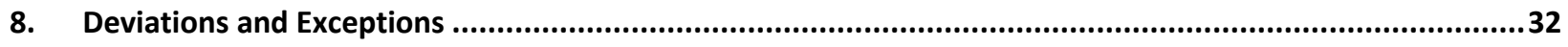

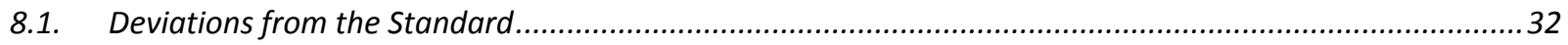

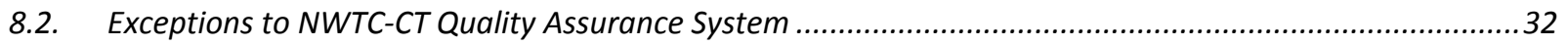

A. Appendix - Pictures of the Test Site from the Turbine Base ..........................................................33

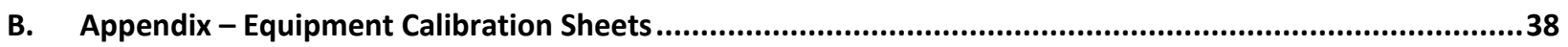




\section{List of Tables}

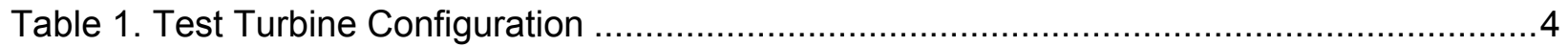

Table 2. Structures close to the test turbine ........................................................................ 7

Table 3. Criteria for test site without site calibration .......................................................... 7

Table 4. Equipment used in the power performance test .............................................. 8

Table 5. Uncertainty values used in the analysis ........................................................ 10

Table 6. Performance at Sea-level air density; $1.225 \mathrm{~kg} / \mathrm{m}^{3}$ for normal power production..........12

Table 7. Performance at site average density; $1.00 \mathrm{~kg} / \mathrm{m}^{3}$ for normal power production ............13

Table 8. Annual energy production (AEP) at sea-level density; $1.225 \mathrm{~kg} / \mathrm{m}^{3}$ for normal power

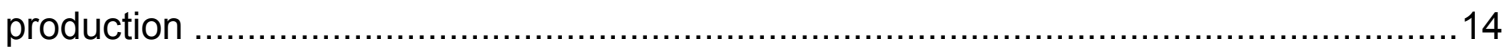

Table 9. Annual energy production at site average density; $1.00 \mathrm{~kg} / \mathrm{m}^{3}$ for normal power

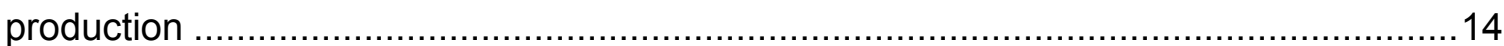

Table 10. Performance at sea-level air density; $1.225 \mathrm{~kg} / \mathrm{m}^{3}$ for optimized power production ....22

Table 11. Performance at site average density; $0.95 \mathrm{~kg} / \mathrm{m}^{3}$ for optimized power production .....23

Table 12. Annual energy production (AEP) at sea-level density; $1.225 \mathrm{~kg} / \mathrm{m}^{3}$ for optimized power

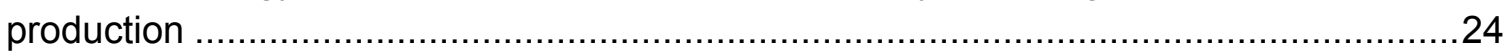

Table 13. Annual energy production at site average density; $0.95 \mathrm{~kg} / \mathrm{m}^{3}$ for optimized power

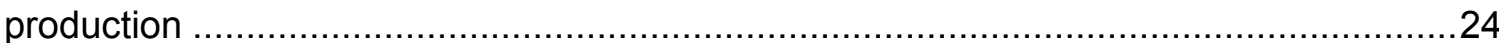




\section{List of Figures}

Figure 1. Power curve summary for the normal configuration ........................................... 2

Figure 2. Power curve summary for the power optimized configuration ................................... 3

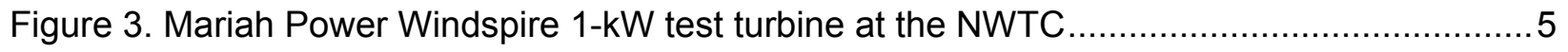

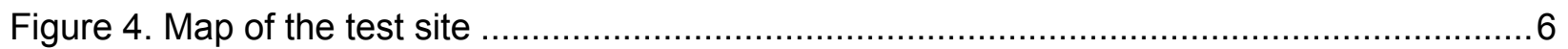

Figure 5. Meteorological tower and instruments ...................................................... 9

Figure 6. Power curve at sea-level density; $1.225 \mathrm{~kg} / \mathrm{m}^{3}$ for normal power production..............15

Figure 7. Power curve at site average density; $1.00 \mathrm{~kg} / \mathrm{m}^{3}$ for normal power production .......... 16

Figure 8. Scatter plot of mean, standard deviation, minimum, and maximum power data for

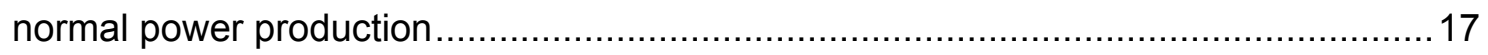

Figure 9. Coefficient of power at sea-level density; $1.225 \mathrm{~kg} / \mathrm{m}^{3}$ for normal power production... 18

Figure 10. Wind turbulence intensity as a function of wind speed during for normal power production ................................................................................................ 19

Figure 11. Wind speed and turbulence intensity as a function of wind direction during test for normal power production ........................................................................ 20

Figure 12. Rotor speed as a function of wind speed (1-minute averages) and binned values for normal power production........................................................................... 21

Figure 13. Power curve at sea-level density; $1.225 \mathrm{~kg} / \mathrm{m}^{3}$ for optimized power production........25

Figure 14. Power curve at site average density; $0.95 \mathrm{~kg} / \mathrm{m}^{3}$ for optimized power production.....26

Figure 15. Scatter plot of mean, standard deviation, minimum, and maximum power data for

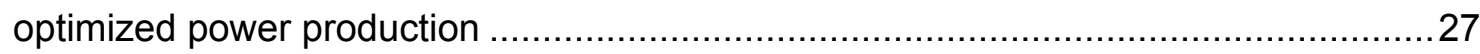

Figure 16. Coefficient of power at sea level density; $1.225 \mathrm{~kg} / \mathrm{m}^{3}$ for optimized power

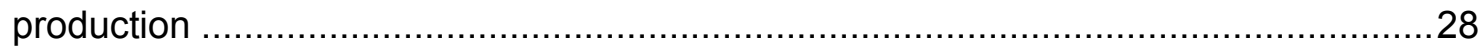

Figure 17. Wind turbulence intensity as a function of wind speed during the test for optimized power production

Figure 18. Wind speed and turbulence intensity as a function of wind direction during the test for optimized power production ................................................................... 30

Figure 19. Rotor speed as a function of wind speed (1-minute averages) and binned values for

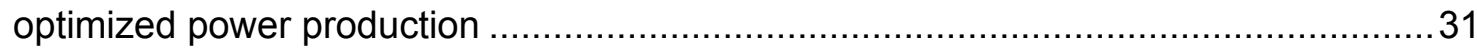




\section{Background}

This test is being conducted as part of the U.S. Department of Energy's (DOE) Independent Testing project. This project was established to help reduce the barriers of wind energy expansion by providing independent testing results for small turbines. In total, four turbines are being tested at the National Wind Technology Center (NWTC) as a part of this project. Power performance testing is one of up to 5 tests that may be performed on the turbines, including duration, safety and function, noise, and power quality tests.

\section{Test Summary}

Figure 1 is a summary of the results of a power performance test that NREL conducted on the Mariah Windspire 1-kW wind turbine. In this test, the Windspire turbine was installed at the NWTC, close to Boulder, Colorado. This test was conducted in accordance with the International Electrotechnical Commission's (IEC) standard, Wind Turbine Generator Systems Part 12: Power Performance Measurements of Electricity Producing Wind Turbines, IEC 6140012-1 Ed.1.0, 2005-12. However, because the Windspire is a small turbine as defined by IEC, NREL also followed Annex $\mathrm{H}$ that applies to small wind turbines. This test report refers to these procedures as the Standard.

During this test, two configurations were tested on the same turbine. In the first configuration, the turbine inverter was optimized for power production. Data collection was not completed with the last required wind speed bin $(14 \mathrm{~m} / \mathrm{s})$ not filled. In the second configuration, the turbine inverter was set for normal power production. Again, data collection was not completed with the last wind speed bin $(14 \mathrm{~m} / \mathrm{s})$ not filled. In both configurations, the inverter experienced failures and the tests were not finished.

In Figure 1, the first summary result, the normal configuration results are shown. Power is normalized to sea-level air density. Additional results are given in Section 7.1. This test was begun on October 7, 2008, and was ended on November 19, 2009. 291.57 hours of valid data were collected during that time. The highest wind speed bin filled was the $13.5 \mathrm{~m} / \mathrm{s}$ bin. The amount of test data is not sufficient to meet the requirements of the Standard, Annex $\mathrm{H}$.

In Figure 2, the second summary result, the optimized power configuration results are shown. Power is normalized to sea-level air density. Additional results are given in Section 7.2. This test was begun on June 12, 2008, and was ended on September 13, 2009. 1023.5 hours of valid data were collected during that time. The highest wind speed bin filled was the $13.5 \mathrm{~m} / \mathrm{s}$ bin. The amount of test data is not sufficient to meet the requirements of the Standard, Annex $\mathrm{H}$. 


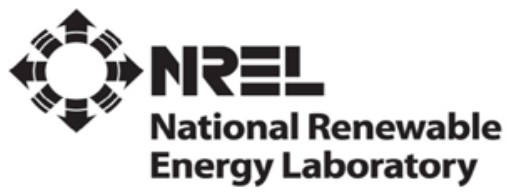

Power Performance Test

Mariah Power Windspire

Sea-Level Density Power Curve

Report Created:

January 23, 2009

Turbine Specifications:

Serial Number:
Rated Power:
Cut-in Wind Speed:
Cut-out Wind Speed:
Rated Wind Speed:
Rotor Diameter:
Control Type:
Pitch Setting:

Site Conditions:

Location

Average Air Density:

Measurement Sectors:

NWTC, Boulder, CO

$1.00 \mathrm{~kg} / \mathrm{m}^{3}$

132 - 323 degrees true

\section{Test Statistics:}

\section{Start Date:}

End Date:

Amount of Data Collected:

Highest Bin Filled:

Test Completed?

October 7, 2008

November 19, 2008

\begin{tabular}{|c|c|c|c|}
\hline $\begin{array}{c}\text { Bin Wind } \\
\text { Speed } \\
(\mathrm{m} / \mathrm{s})\end{array}$ & $\begin{array}{c}\text { Bin } \\
\text { Power } \\
(\mathbf{k W})\end{array}$ & $\begin{array}{c}\text { Number } \\
\text { Data } \\
\text { Points }\end{array}$ & Cp \\
\hline 0.54 & -0.01 & 477 & -10.70 \\
\hline 1.03 & -0.01 & 905 & -1.56 \\
\hline 1.52 & -0.01 & 1,595 & -0.48 \\
\hline 2.01 & -0.01 & 2,228 & -0.21 \\
\hline 2.50 & -0.01 & 2,343 & -0.11 \\
\hline 2.99 & -0.01 & 2,084 & -0.06 \\
\hline 3.48 & 0.00 & 1,335 & -0.02 \\
\hline 3.98 & 0.01 & 910 & 0.02 \\
\hline 4.50 & 0.03 & 670 & 0.07 \\
\hline 4.99 & 0.05 & 599 & 0.10 \\
\hline 5.49 & 0.09 & 567 & 0.11 \\
\hline 6.00 & 0.13 & 573 & 0.13 \\
\hline 6.50 & 0.18 & 510 & 0.14 \\
\hline 7.01 & 0.25 & 472 & 0.16 \\
\hline 7.49 & 0.32 & 409 & 0.17 \\
\hline 7.98 & 0.41 & 351 & 0.18 \\
\hline 8.50 & 0.52 & 291 & 0.19 \\
\hline 8.99 & 0.64 & 307 & 0.19 \\
\hline 9.49 & 0.76 & 253 & 0.20 \\
\hline 9.98 & 0.88 & 189 & 0.19 \\
\hline 10.48 & 0.96 & 132 & 0.18 \\
\hline 10.99 & 1.02 & 114 & 0.17 \\
\hline 11.48 & 1.06 & 65 & 0.15 \\
\hline 11.99 & 1.09 & 42 & 0.14 \\
\hline 12.49 & 0.99 & 38 & 0.11 \\
\hline 13.02 & 0.96 & 21 & 0.10 \\
\hline 13.47 & 0.99 & 14 & 0.09 \\
\hline
\end{tabular}

291.57

$13.50 \mathrm{~m} / \mathrm{s}$

No

Sea-Level Air Density Normalized Power Curve Mariah Power Windspire

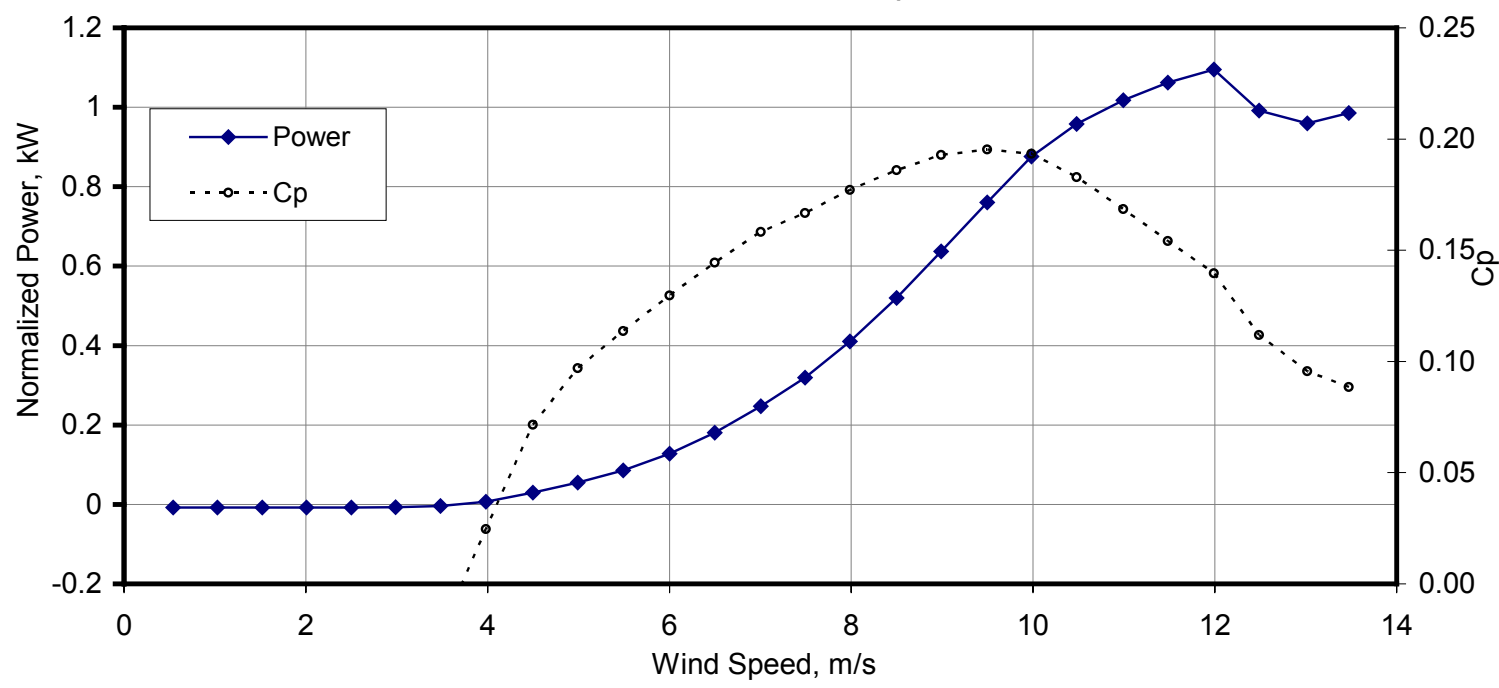

Figure 1. Power curve summary for the normal configuration 
Energy Laboratory

Power Performance Test

Mariah Power Windspire

Optimized inverter

Sea-Level Density Power Curve

Report Created:

January 26, 2009

Turbine Specifications:

$$
\begin{aligned}
& \text { Serial Number: } \\
& \text { Rated Power: } \\
& \text { Cut-in Wind Speed: } \\
& \text { Cut-out Wind Speed: } \\
& \text { Rated Wind Speed: } \\
& \text { Rotor Diameter: } \\
& \text { Control Type: } \\
& \text { Pitch Setting: }
\end{aligned}
$$

Site Conditions:

Location

Average Air Density:

Measurement Sectors:

NWTC, Boulder, CO

0.97

$132-323$

$\mathrm{kg} / \mathrm{m}^{3}$

degrees true

\section{$\underline{\text { Test Statistics: }}$}

Start Date:

End Date

A mount of Data Collected:

\begin{tabular}{|c|c|c|c|}
\hline $\begin{array}{l}\text { Bin Wind } \\
\text { Speed } \\
\text { (m/s) }\end{array}$ & $\begin{array}{l}\text { Bin } \\
\text { Power } \\
\text { (kW) }\end{array}$ & $\begin{array}{l}\text { Number } \\
\text { Data } \\
\text { Points }\end{array}$ & $\mathrm{Cp}$ \\
\hline 0.55 & -0.01 & 1,548 & -10.60 \\
\hline 1.02 & -0.01 & 3,520 & -1.68 \\
\hline 1.52 & -0.01 & 6,102 & -0.51 \\
\hline 2.01 & -0.01 & 9,108 & -0.22 \\
\hline 2.50 & -0.01 & 9,709 & -0.11 \\
\hline 2.99 & -0.01 & 8,497 & -0.06 \\
\hline 3.48 & -0.01 & 6,251 & -0.03 \\
\hline 3.98 & 0.01 & 3,977 & 0.02 \\
\hline 4.48 & 0.02 & 2,690 & 0.06 \\
\hline 4.99 & 0.05 & 2,031 & 0.09 \\
\hline 5.49 & 0.08 & 1,576 & 0.11 \\
\hline 6.00 & 0.12 & 1,391 & 0.12 \\
\hline 6.48 & 0.16 & 1,124 & 0.13 \\
\hline 6.99 & 0.22 & 953 & 0.14 \\
\hline 7.49 & 0.29 & 741 & 0.15 \\
\hline 7.99 & 0.37 & 559 & 0.16 \\
\hline 8.47 & 0.48 & 411 & 0.17 \\
\hline 8.98 & 0.60 & 331 & 0.18 \\
\hline 9.48 & 0.72 & 206 & 0.19 \\
\hline 10.00 & 0.86 & 181 & 0.19 \\
\hline 10.50 & 0.96 & 146 & 0.18 \\
\hline 10.99 & 1.08 & 121 & 0.18 \\
\hline 11.47 & 1.15 & 80 & 0.17 \\
\hline 12.02 & 1.24 & 71 & 0.16 \\
\hline 12.50 & 1.29 & 43 & 0.14 \\
\hline 13.02 & 1.32 & 29 & 0.13 \\
\hline 13.56 & 1.37 & 14 & 0.12 \\
\hline
\end{tabular}

Highest Bin Filled:

Test Completed?

June 12, 2008

September 13, 2008

1023.50 hours

13.50

No

Sea-Level Air Density Normalized Power Curve Mariah Power Windspire

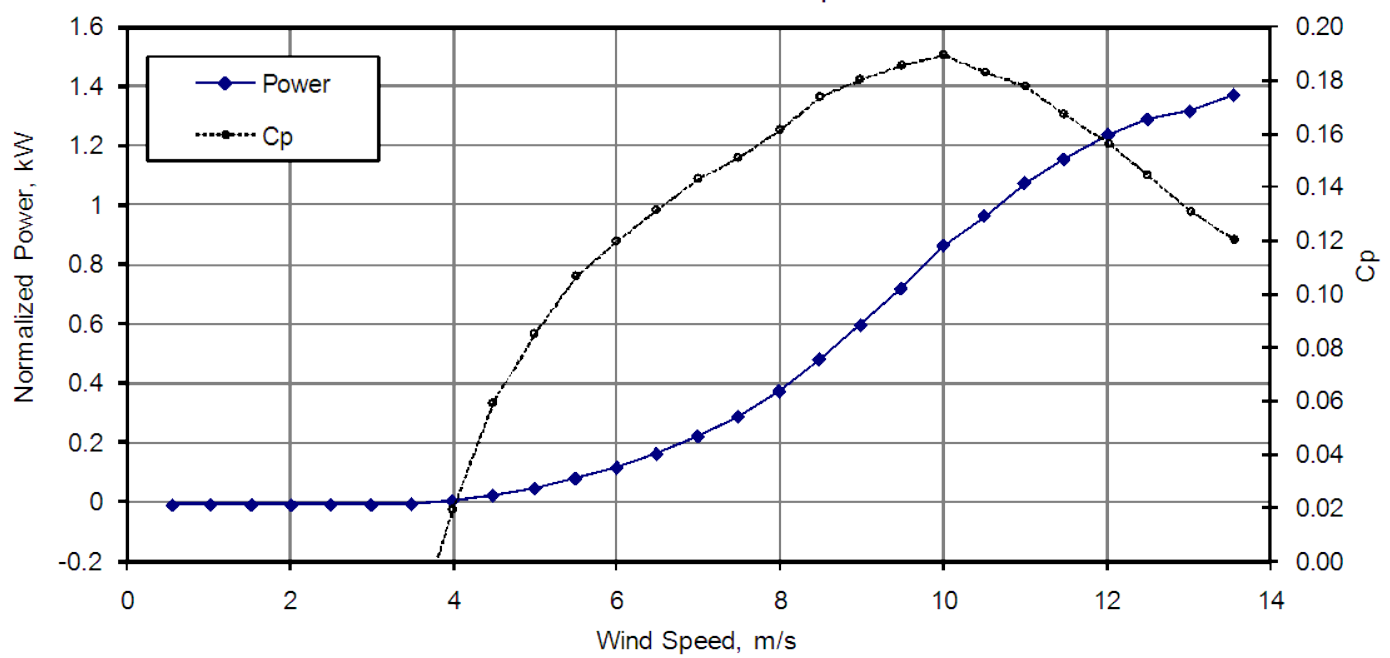

Figure 2. Power curve summary for the power optimized configuration 


\section{Test Turbine Configuration}

Table 1 lists the configuration of the Windspire that was tested at the NWTC.

Table 1. Test Turbine Configuration

\begin{tabular}{|l|l|}
\hline Turbine make, model, serial number, production year & Mariah Power, Windspire, 800021, 2008 \\
\hline Horizontal or vertical axis turbine & Vertical \\
\hline Rotor diameter $(\mathrm{m})$ & 3.05 \\
\hline Rotor height $(\mathrm{m})$ & 6.10 \\
\hline Rotor center height $(\mathrm{m})$ & 6.10 \\
\hline Tower type & Tubular \\
\hline Rated electrical power $(\mathrm{kW})$ & 1 \\
\hline Rated wind speed $(\mathrm{m} / \mathrm{s})$ & 11.0 \\
\hline Rotor speed range $(\mathrm{rpm})$ & $0-500$ \\
\hline Fixed or variable pitch & Fixed \\
\hline Number of blades/airfoils & 3 \\
\hline Blade pitch angle (deg) & 0 \\
\hline Blade make, type, serial number & Mariah Power, Airfoil \\
\hline $\begin{array}{l}\text { Description of control system (device \& software } \\
\text { version) }\end{array}$ & Windspire 1.2G \\
\hline
\end{tabular}

The rotor diameter was verified by measurements. 


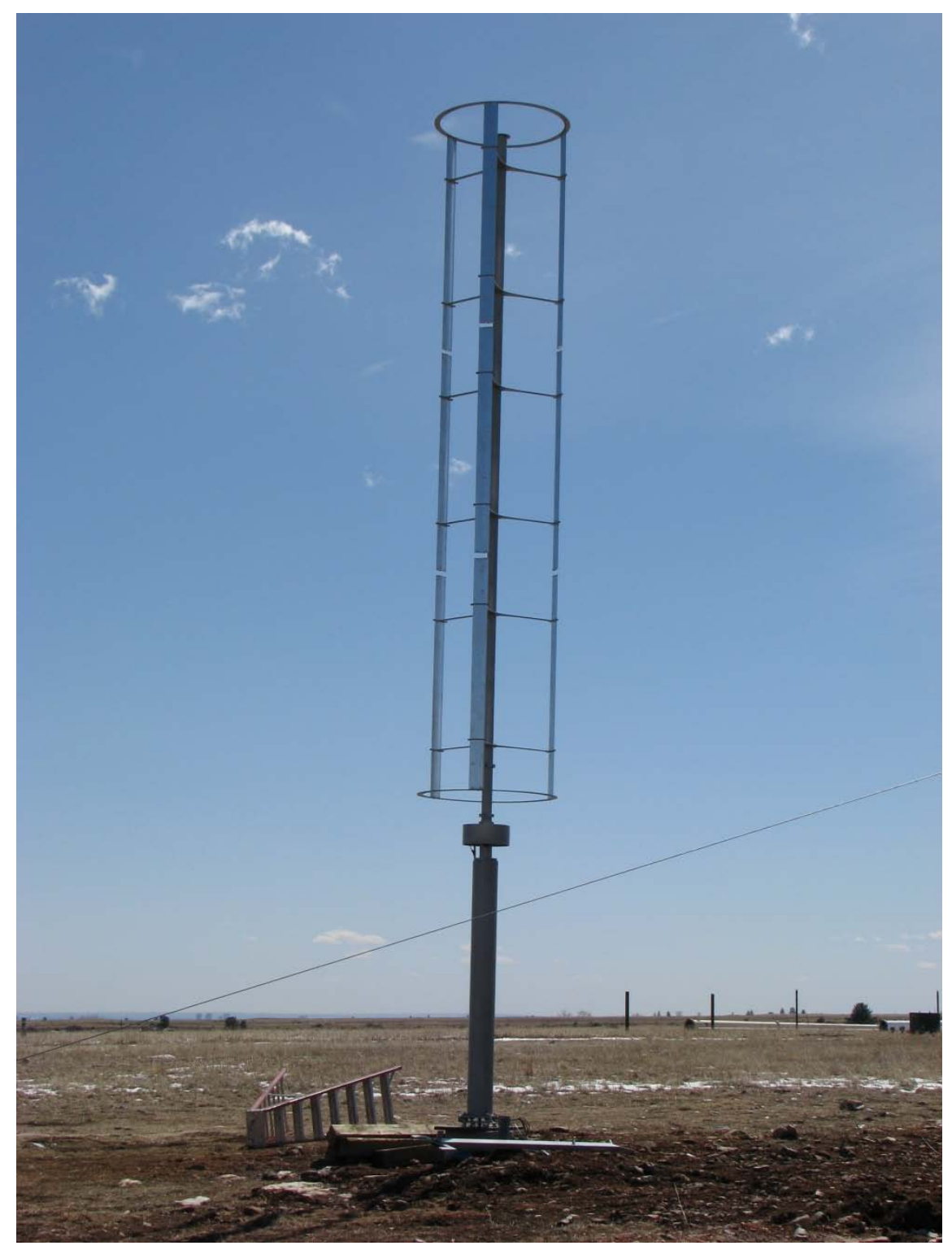

Figure 3. Mariah Power Windspire 1-kW test turbine at the NWTC 


\section{Test Site Description}

The test turbine is located at site 3.3C at the NWTC, located 8 miles south of Boulder, Colorado. The terrain primarily consists of mostly flat terrain with short vegetation. The test site has prevailing wind bearing at 292 degrees relative to true north. For measurements where it is important to accurately measure wind speed, NREL used data obtained when wind direction is between $132^{\circ}$ and $323^{\circ}$ degrees true. In this measurement sector, the influence of terrain and obstructions on the anemometer is small. Figure 4 shows the turbine and meteorological tower locations. This figure also shows nearby obstructions and topographical features of the site. Sizes and distances of nearby obstructions are provided in Table 2.

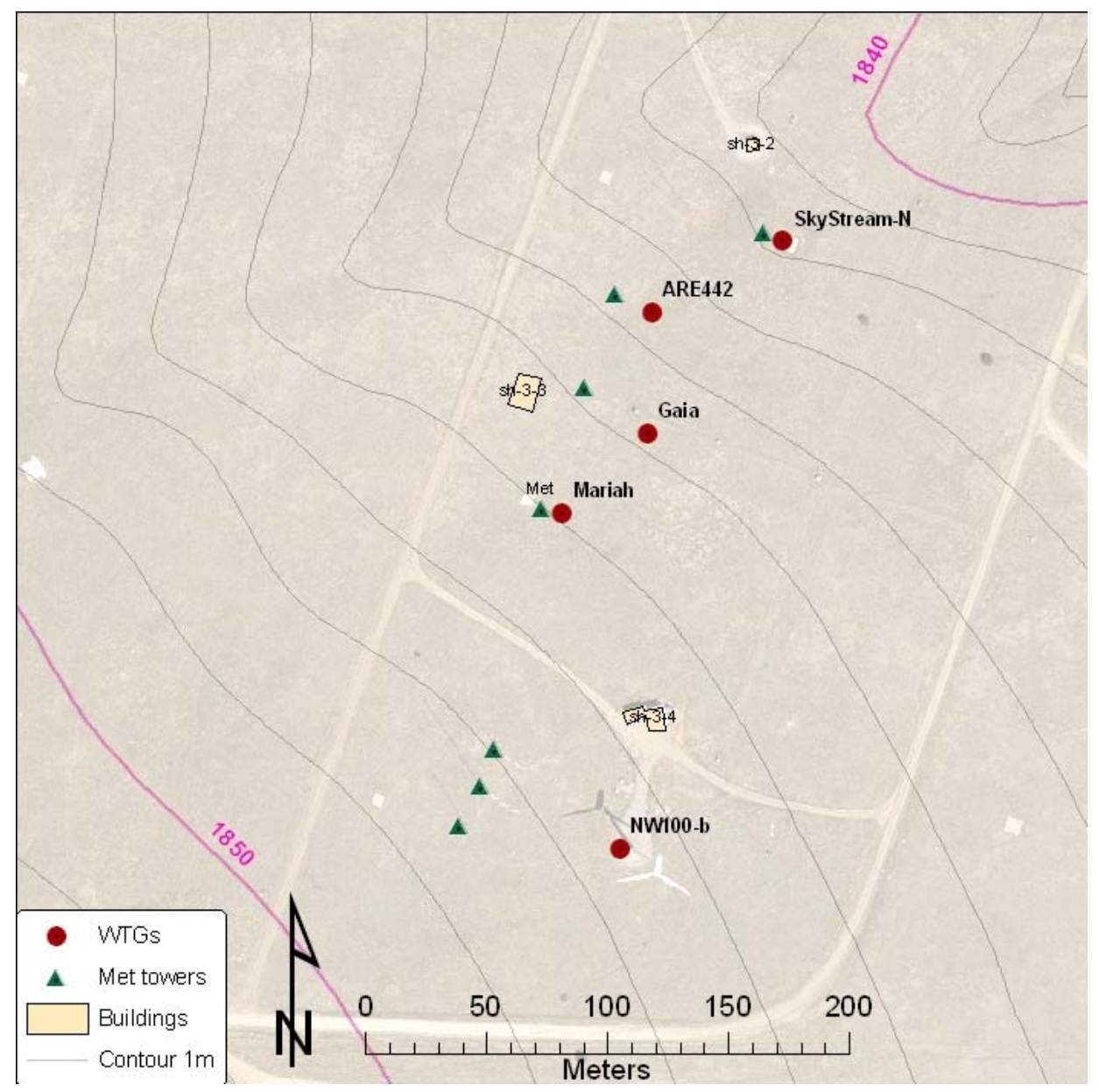

Figure 4. Map of the test site 
Table 2. Structures close to the test turbine

\begin{tabular}{|l|c|c|c|c|}
\hline Designation & $\begin{array}{c}\text { Bearing from } \\
\text { Test Turbine } \\
\text { (deg. T) }\end{array}$ & $\begin{array}{c}\text { Distance from } \\
\text { Test Turbine } \\
(\mathrm{m})\end{array}$ & $\begin{array}{c}\text { Obstruction } \\
\text { Height } \\
(\mathrm{m})\end{array}$ & $\begin{array}{c}\text { Rotor Diameter } \\
\text { or Obstruction } \\
\text { Width } \\
(\mathrm{m})\end{array}$ \\
\hline $\begin{array}{l}\text { Windspire } \\
\text { met }\end{array}$ & 293 & 7.0 & 4.6 & 0.3 \\
\hline Data shed & 341 & 60.0 & 3.1 & 7.0 \\
\hline ARE 442 & 26 & 303.4 & 31.0 & 7.3 \\
\hline ARE 442 met & 13 & 299.3 & 31.0 & 0.4 \\
\hline Gaia & 47 & 168.9 & 18.2 & 13.0 \\
\hline Gaia met & 9 & 153.3 & 8.2 & 0.4 \\
\hline
\end{tabular}

NREL completed a site assessment to determine if the site fails the requirements of Annex A of the Standard and would therefore require a site calibration. Table 3 shows the results from the site assessment. Based on the site assessment results, a site calibration is not required.

Table 3. Criteria for test site without site calibration

\begin{tabular}{|l|c|c|c|c|}
\hline \multicolumn{1}{|c|}{ Description } & Distance & $\begin{array}{c}\text { Sector } \\
(\mathrm{deg})\end{array}$ & $\begin{array}{c}\text { Test Site } \\
\text { Condition }\end{array}$ & Pass/Fail \\
\hline Maximum slope of best fit plane $<3 \%$ & $<2 \mathrm{~L}$ & 360 & $2.6 \%$ & Pass \\
\hline $\begin{array}{l}\text { Maximum variation from best fit plane }< \\
0.08 \mathrm{D}\end{array}$ & $<2 \mathrm{~L}$ & 360 & 0.04 & Pass \\
\hline Maximum slope of best fit plane $<5 \%$ & $2-4 \mathrm{~L}$ & $\mathrm{In}$ & $1.7 \%$ & Pass \\
\hline $\begin{array}{l}\text { Maximum variation from best fit plane }< \\
0.15 \mathrm{D}\end{array}$ & $2-4 \mathrm{~L}$ & $\mathrm{In}$ & 0.04 & Pass \\
\hline Steepest slope maximum <10\% & $2-4 \mathrm{~L}$ & Out & $3.4 \%$ & Pass \\
\hline Maximum slope of best fit plane $<10 \%$ & $4-8 \mathrm{~L}$ & $\mathrm{In}$ & $2.0 \%$ & Pass \\
\hline $\begin{array}{l}\text { Maximum variation from best fit plane }< \\
0.15 \mathrm{D}\end{array}$ & $4-8 \mathrm{~L}$ & $\mathrm{In}$ & 0.04 & Pass \\
\hline No neighboring and operating turbines & $<2 \mathrm{D}_{\mathrm{n}}$ & 360 & 0 & Pass \\
\hline No obstacles & $<2 \mathrm{D}_{\mathrm{e}}$ & 360 & 0 & Pass \\
\hline
\end{tabular}

$\mathrm{D}=$ test turbine rotor diameter

$\mathrm{L}=$ distance between test turbine and meteorological tower

$D_{e}=$ equivalent diameter of obstacle

In = inside preliminary measurement sector

Out $=$ outside preliminary measurement sector

The Mariah Windspire was connected to the electrical grid at a nominal voltage of $120 \mathrm{VAC}$ at a frequency of $60 \mathrm{~Hz}$. The grid tolerances are $5 \%$ for voltage amplitude and $1 \%$ for frequency. 


\section{Description of Test Equipment}

All test equipment was calibrated and the calibration sheets are included in Appendix B. Table 4 shows the equipment used and calibration due dates. Figure 5 shows placement of the meteorological instruments on the tower. The primary anemometer was sent out for recalibration after the test period. The difference between the pre-test and post-test calibrations was within the tolerances allowed by the standard.

Table 4. Equipment used in the power performance test

\begin{tabular}{|c|c|c|c|}
\hline Instrument & Make and Model & Serial Number & Calibration Due Date \\
\hline Power transducer & Second Wind, Phaser 5FM-4A20 & 02061 & 8 Feb 2009 \\
\hline Voltage transformers & Ohio Semitronics, VT7-010E-11 & 08010700 & $\begin{array}{l}\text { Calibrated with power } \\
\text { transducer }\end{array}$ \\
\hline Primary anemometer & Thies, First Class & 0707894 & 27 Feb 2009 \\
\hline $\begin{array}{l}\text { Reference } \\
\text { anemometer }\end{array}$ & NRG, Max 40 & $\begin{array}{l}179500049701 \\
179500049703\end{array}$ & In situ \\
\hline Wind vane & $\begin{array}{l}\text { Met One, } 020 \mathrm{C} \text { with aluminum } \\
\text { vane }\end{array}$ & W5515 & 27 Feb 2009 \\
\hline $\begin{array}{l}\text { Pressure sensor } \\
\text { (replaced during test) }\end{array}$ & Vaisala, PTB101B & $\begin{array}{l}\text { C1040008 } \\
\text { Y3350027 }\end{array}$ & $\begin{array}{l}29 \text { Oct } 2008 \\
29 \text { Nov } 2009\end{array}$ \\
\hline $\begin{array}{l}\text { Temperature sensor } \\
\text { (replaced during test) }\end{array}$ & Met One, T200 & $\begin{array}{l}0673553 \\
0602948\end{array}$ & $\begin{array}{l}29 \text { Oct } 2008 \\
10 \text { Oct } 2009\end{array}$ \\
\hline Precipitation sensor & Campbell Scientific, 237 & None & In situ \\
\hline $\begin{array}{l}\text { Data acquisition } \\
\text { system }\end{array}$ & $\begin{array}{l}\text { Compact DAQ w/LabVIEW } \\
\text { cDAQ backplane } \\
\text { NI } 9229 \\
\text { NI } 9217 \\
\text { NI } 9205\end{array}$ & $\begin{array}{l}\text { 12E4D23 } \\
\text { 12B6DD2 } \\
\text { 12BD192 } \\
\text { 12E9C3E }\end{array}$ & $\begin{array}{l}28 \text { Jun } 2008 \\
06 \text { Jul } 2008 \\
08 \text { Oct } 2008 \\
\text { Modules post-test } \\
\text { calibrated on } 6 \text { May } \\
2009 \text { and found in } \\
\text { compliance }\end{array}$ \\
\hline
\end{tabular}




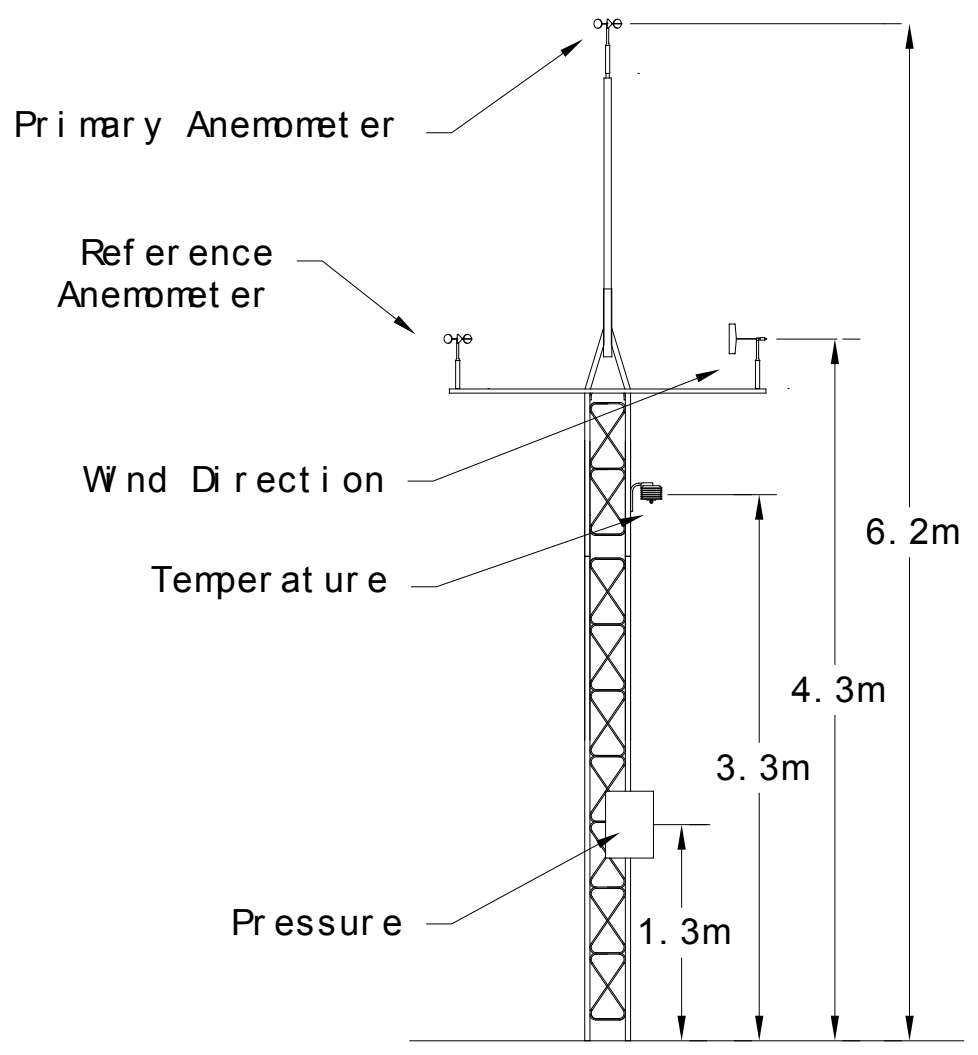

Figure 5. Meteorological tower and instruments

To ensure that only data obtained during normal operation of the turbine are used in the analysis, and to ensure data are not corrupted, data sets are excluded from the database under the following circumstances:

- external conditions other than wind speed are out of the normal range for turbine operation,

- turbine cannot operate because of a turbine fault condition, and,

- turbine is manually shut down or in a test or maintenance operating mode.

Two methods are used to track when any of these conditions occur during the test. The first method, the logbook will be checked for such events. The other method is a signal from the turbine that indicates when the turbine is braked. 


\section{Description of Test Procedure}

The test was conducted according to the procedures in the Standard. The sampling rate was $10 \mathrm{kHz}$, decimated to $40 \mathrm{~Hz}$. The averaging time was 1 minute for the mean values. Standard deviation, minimum, and maximum values for each averaging period were also collected.

The turbine status signal for the Windspire was obtained by checking the release of the brake. The status signal indicated if the turbine was braked or not.

Only database A is reported since the Windspire does not have a cut-out wind speed.

Table 5 gives the uncertainty sources and values used in the analysis.

Table 5. Uncertainty values used in the analysis

\begin{tabular}{|c|c|c|}
\hline Component & Uncertainty & Source \\
\hline \multicolumn{3}{|l|}{ Power } \\
\hline $\begin{array}{l}\text { Current sensor/signal } \\
\text { conditioner }\end{array}$ & $6.00 \mathrm{~W}$ & Specifications (specs) \\
\hline Power transducer & $0.12 \%$ & Specs \\
\hline Data acquisition & $40.50 W+0.08 \%$ & Specs \\
\hline Resistor & $0.01 \%$ & Specs \\
\hline \multicolumn{3}{|l|}{ Wind Speed } \\
\hline Calibration & $0.02 \mathrm{~m} / \mathrm{s}$ & Calibration sheet \\
\hline Operational characteristics & $0.05 \mathrm{~m} / \mathrm{s}+0.52 \%$ & IEC \\
\hline Mounting effects & $1.00 \%$ & Assumption \\
\hline Terrain effects & $2.00 \%$ & IEC \\
\hline Data acquisition & $<0.01 \mathrm{~m} / \mathrm{s}$ & Assumption \\
\hline \multicolumn{3}{|l|}{ Temperature } \\
\hline Temperature sensor & $0.15^{\circ} \mathrm{C}$ & Specs \\
\hline Radiation shielding & $1.15^{\circ} \mathrm{C}$ & Assumption \\
\hline Mounting effects & $0.09^{\circ} \mathrm{C}$ & IEC method \\
\hline Data acquisition & $0.35^{\circ} \mathrm{C}$ & Specs \\
\hline \multicolumn{3}{|l|}{ Air Pressure } \\
\hline Pressure sensor & $0.20 \mathrm{kPa}$ & Instrument specs. \\
\hline Mounting effects & $<0.01 \mathrm{kPa}$ & IEC method \\
\hline Data acquisition & $0.06 \mathrm{kPa}$ & Specs \\
\hline
\end{tabular}




\section{Test Results}

Test results are given for two turbine configurations. The first section is for the normal configuration. The second section is for the power optimized configuration.

\subsection{Results of Power Performance Test for the Normal Configuration}

\subsubsection{Tabular Results for Normal Power Production}

Table 6 through Table 9 provide the power performance test results for the normal configuration in tabular format. Table 6 shows the binned power performance results at sea-level normalized air density for normal power production. Table 7 shows the binned power performance results for the site average air density at the NWTC for normal power production. 
Table 6. Performance at Sea-level air density; $1.225 \mathrm{~kg} / \mathrm{m}^{3}$ for normal power production

\begin{tabular}{|c|c|c|c|c|c|c|c|}
\hline \multicolumn{8}{|c|}{ Measured power curve (database A) } \\
\hline \multicolumn{4}{|c|}{ Reference air density: $1.225 \mathrm{~kg} / \mathrm{m}^{3}$} & \multirow[b]{2}{*}{$\begin{array}{l}\text { Number of } \\
\text { 1-Minute } \\
\text { Data Sets }\end{array}$} & \multirow{2}{*}{$\begin{array}{c}\text { Category A } \\
\text { Standard } \\
\text { Uncertainty }\end{array}$} & \multirow[b]{2}{*}{$\begin{array}{c}\text { Category B } \\
\text { Standard } \\
\text { Uncertainty } \\
(\mathrm{kW})\end{array}$} & \multirow{2}{*}{$\begin{array}{c}\text { Combined } \\
\text { Standard } \\
\text { Uncertainty } \\
(\mathrm{kW})\end{array}$} \\
\hline$(\mathrm{m} / \mathrm{s})$ & $\begin{array}{l}\text { Wind } \\
\text { Speed } \\
(\mathrm{m} / \mathrm{s})\end{array}$ & \begin{tabular}{|c|} 
Normalized \\
Power \\
Output \\
(kW)
\end{tabular} & $\mathrm{C}_{\mathrm{p}}$ & & & & \\
\hline 2.5 & 2.50 & -0.01 & -0.11 & 2343 & 0.00 & 0.04 & 0.04 \\
\hline 3 & 2.99 & -0.01 & -0.06 & 2084 & 0.00 & 0.04 & 0.04 \\
\hline 3.5 & 3.48 & 0.00 & -0.02 & 1335 & 0.00 & 0.04 & 0.04 \\
\hline 4 & 3.98 & 0.01 & 0.02 & 910 & 0.00 & 0.04 & 0.04 \\
\hline 4.5 & 4.50 & 0.03 & 0.07 & 670 & 0.00 & 0.04 & 0.04 \\
\hline 5 & 4.99 & 0.05 & 0.10 & 599 & 0.00 & 0.04 & 0.04 \\
\hline 5.5 & 5.49 & 0.09 & 0.11 & 567 & 0.00 & 0.04 & 0.04 \\
\hline 6 & 6.00 & 0.13 & 0.13 & 573 & 0.00 & 0.04 & 0.04 \\
\hline 6.5 & 6.50 & 0.18 & 0.14 & 510 & 0.00 & 0.04 & 0.04 \\
\hline 7 & 7.01 & 0.25 & 0.16 & 472 & 0.00 & 0.05 & 0.05 \\
\hline 7.5 & 7.49 & 0.32 & 0.17 & 409 & 0.00 & 0.05 & 0.05 \\
\hline 8 & 7.98 & 0.41 & 0.18 & 351 & 0.00 & 0.05 & 0.05 \\
\hline 8.5 & 8.50 & 0.52 & 0.19 & 291 & 0.00 & 0.06 & 0.06 \\
\hline 9 & 8.99 & 0.64 & 0.19 & 307 & 0.00 & 0.07 & 0.07 \\
\hline 9.5 & 9.49 & 0.76 & 0.20 & 253 & 0.00 & 0.07 & 0.07 \\
\hline 10 & 9.98 & 0.88 & 0.19 & 189 & 0.00 & 0.07 & 0.07 \\
\hline 10.5 & 10.48 & 0.96 & 0.18 & 132 & 0.01 & 0.06 & 0.06 \\
\hline 11 & 10.99 & 1.02 & 0.17 & 114 & 0.01 & 0.05 & 0.05 \\
\hline 11.5 & 11.48 & 1.06 & 0.15 & 65 & 0.02 & 0.05 & 0.05 \\
\hline 12 & 11.99 & 1.09 & 0.14 & 42 & 0.03 & 0.04 & 0.05 \\
\hline 12.5 & 12.49 & 0.99 & 0.11 & 38 & 0.03 & 0.07 & 0.08 \\
\hline 13 & 13.02 & 0.96 & 0.10 & 21 & 0.04 & 0.04 & 0.06 \\
\hline 13.5 & 13.47 & 0.99 & 0.09 & 14 & 0.06 & 0.04 & 0.07 \\
\hline
\end{tabular}


Table 7. Performance at site average density; $1.00 \mathrm{~kg} / \mathrm{m}^{3}$ for normal power production

\begin{tabular}{|c|c|c|c|c|c|c|c|}
\hline \multicolumn{8}{|c|}{ Measured power curve (database A) } \\
\hline \multicolumn{4}{|c|}{ Reference air density: $1.00 \mathrm{~kg} / \mathrm{m}^{3}$} & \multirow[b]{2}{*}{$\begin{array}{l}\text { Number of } \\
\text { 1-Minute } \\
\text { Data Sets }\end{array}$} & \multirow{2}{*}{$\begin{array}{c}\text { Category A } \\
\text { Standard } \\
\text { Uncertainty }\end{array}$} & \multirow[b]{2}{*}{$\begin{array}{c}\text { Category B } \\
\text { Standard } \\
\text { Uncertainty } \\
(\mathrm{kW})\end{array}$} & \multirow{2}{*}{$\begin{array}{c}\text { Combined } \\
\text { Standard } \\
\text { Uncertainty } \\
\\
(\mathrm{kW})\end{array}$} \\
\hline$(\mathrm{m} / \mathrm{s})$ & $\begin{array}{l}\text { Wind } \\
\text { Speed } \\
(\mathrm{m} / \mathrm{s})\end{array}$ & \begin{tabular}{|c|} 
Normalized \\
Power \\
Output \\
(kW) \\
\end{tabular} & $\mathrm{C}_{\mathrm{p}}$ & & & & \\
\hline 2.5 & 2.50 & -0.01 & -0.11 & 2343 & 0.00 & 0.04 & 0.04 \\
\hline 3 & 2.99 & -0.01 & -0.06 & 2084 & 0.00 & 0.04 & 0.04 \\
\hline 3.5 & 3.48 & 0.00 & -0.02 & 1335 & 0.00 & 0.04 & 0.04 \\
\hline 4 & 3.98 & 0.01 & 0.02 & 910 & 0.00 & 0.04 & 0.04 \\
\hline 4.5 & 4.50 & 0.02 & 0.07 & 670 & 0.00 & 0.04 & 0.04 \\
\hline 5 & 4.99 & 0.04 & 0.10 & 599 & 0.00 & 0.04 & 0.04 \\
\hline 5.5 & 5.49 & 0.07 & 0.11 & 567 & 0.00 & 0.04 & 0.04 \\
\hline 6 & 6.00 & 0.10 & 0.13 & 573 & 0.00 & 0.04 & 0.04 \\
\hline 6.5 & 6.50 & 0.15 & 0.14 & 510 & 0.00 & 0.04 & 0.04 \\
\hline 7 & 7.01 & 0.20 & 0.16 & 472 & 0.00 & 0.04 & 0.04 \\
\hline 7.5 & 7.49 & 0.26 & 0.17 & 409 & 0.00 & 0.05 & 0.05 \\
\hline 8 & 7.98 & 0.33 & 0.18 & 351 & 0.00 & 0.05 & 0.05 \\
\hline 8.5 & 8.50 & 0.42 & 0.19 & 291 & 0.00 & 0.05 & 0.05 \\
\hline 9 & 8.99 & 0.52 & 0.19 & 307 & 0.00 & 0.06 & 0.06 \\
\hline 9.5 & 9.49 & 0.62 & 0.20 & 253 & 0.00 & 0.06 & 0.06 \\
\hline 10 & 9.98 & 0.72 & 0.19 & 189 & 0.00 & 0.06 & 0.06 \\
\hline 10.5 & 10.48 & 0.78 & 0.18 & 132 & 0.01 & 0.05 & 0.05 \\
\hline 11 & 10.99 & 0.83 & 0.17 & 114 & 0.01 & 0.05 & 0.05 \\
\hline 11.5 & 11.48 & 0.87 & 0.15 & 65 & 0.01 & 0.05 & 0.05 \\
\hline 12 & 11.99 & 0.89 & 0.14 & 42 & 0.02 & 0.04 & 0.05 \\
\hline 12.5 & 12.49 & 0.81 & 0.11 & 38 & 0.02 & 0.06 & 0.07 \\
\hline 13 & 13.02 & 0.78 & 0.10 & 21 & 0.03 & 0.04 & 0.05 \\
\hline 13.5 & 13.47 & 0.80 & 0.09 & 14 & 0.05 & 0.04 & 0.06 \\
\hline
\end{tabular}


Table 8 shows the annual energy production at sea-level normalized air density for normal power production. Table 9 shows the annual energy production at the site average air density for the NWTC for normal power production. A cut-out wind speed of $25 \mathrm{~m} / \mathrm{s}$ is assumed for analysis purposes, though the turbine does not have a cut out wind speed.

Table 8. Annual energy production (AEP) at sea-level density; $1.225 \mathrm{~kg} / \mathrm{m}^{3}$ for normal power production

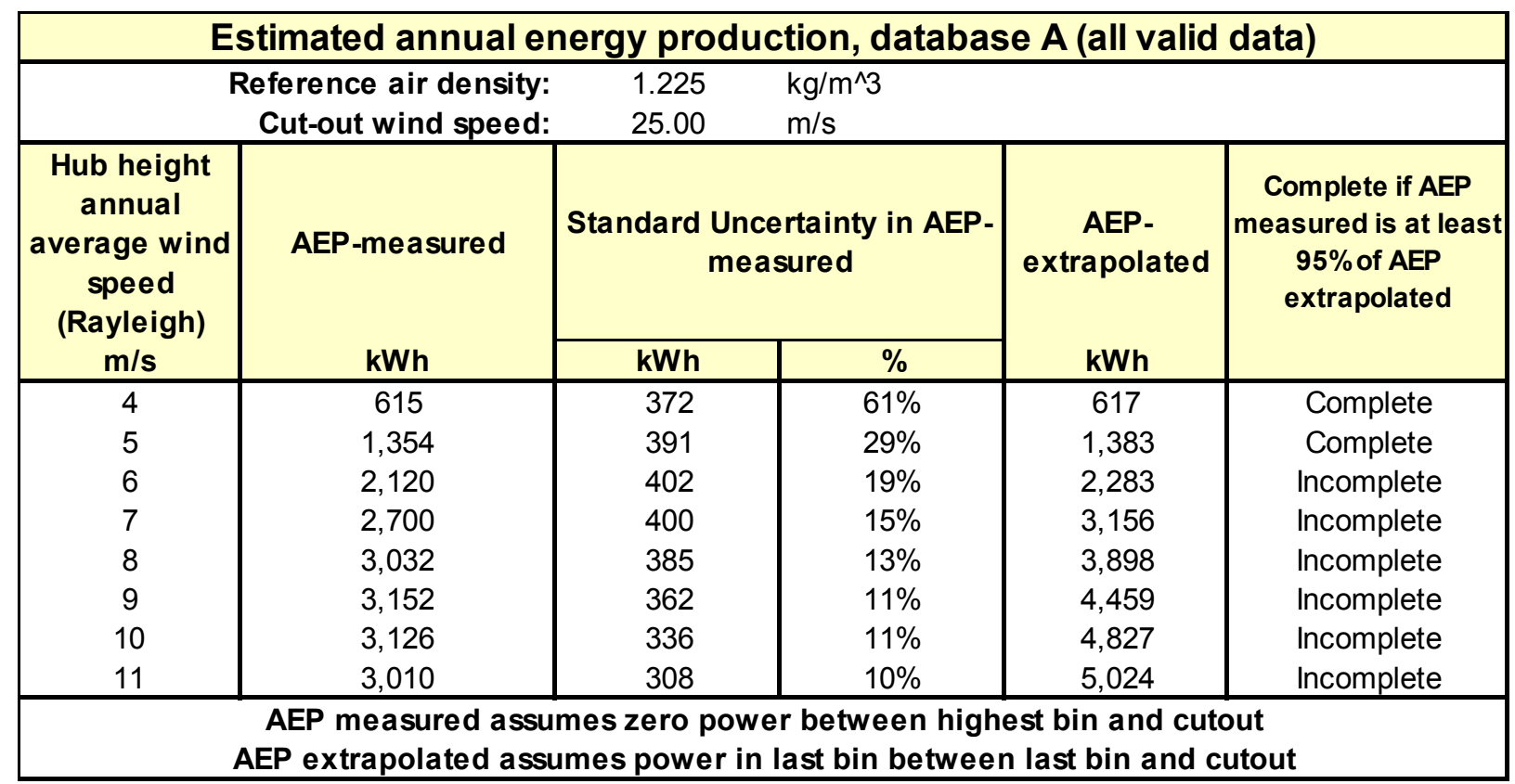

Table 9. Annual energy production at site average density; $1.00 \mathrm{~kg} / \mathrm{m}^{3}$ for normal power production

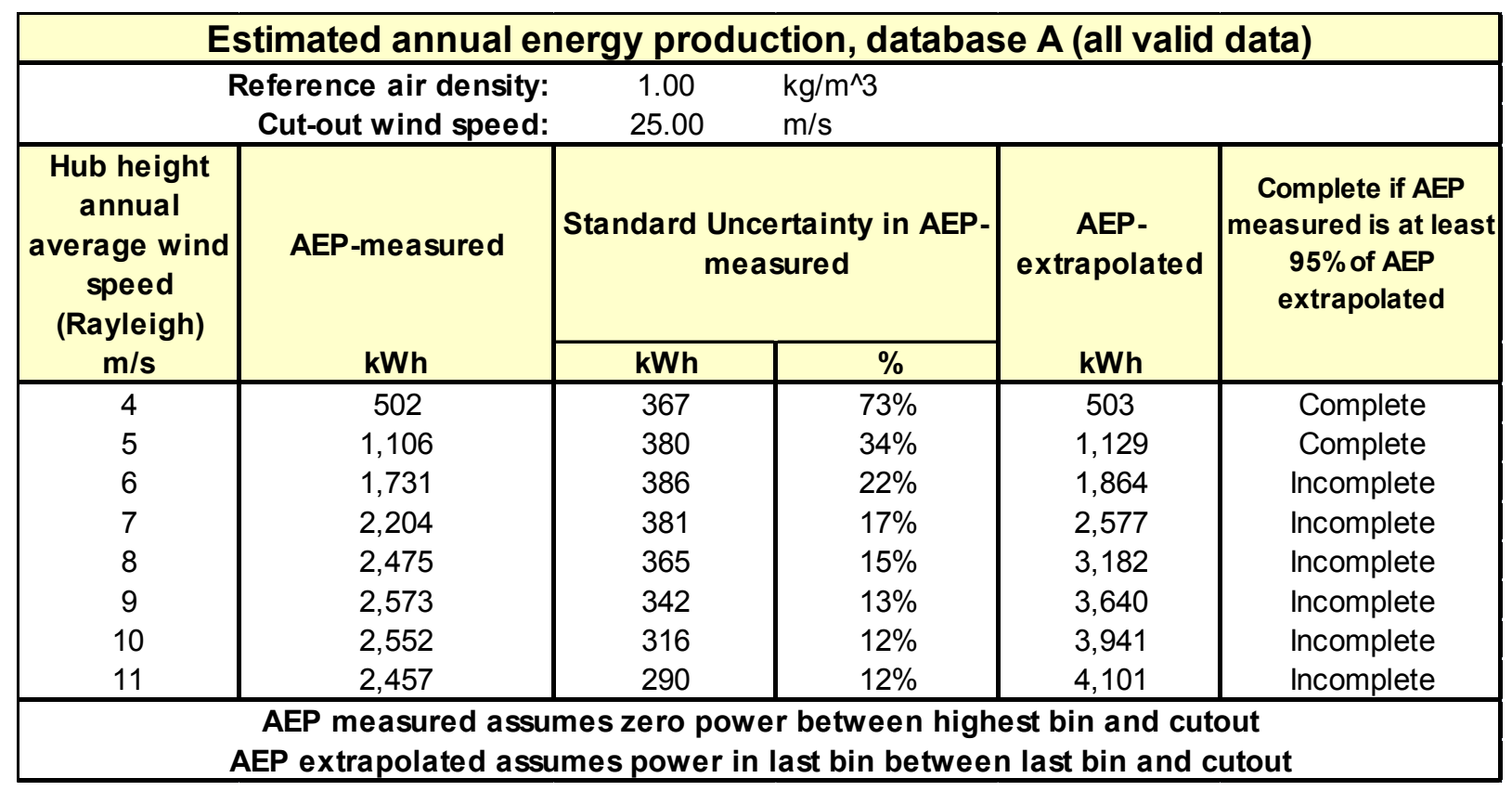




\subsubsection{Graphical Results for Normal Power Production}

Figure 6 through Figure 12 show the results of the power performance test for normal power production in graphical format. Figure 6 shows a plot of the binned power curve normalized to sea level air density for normal power production.

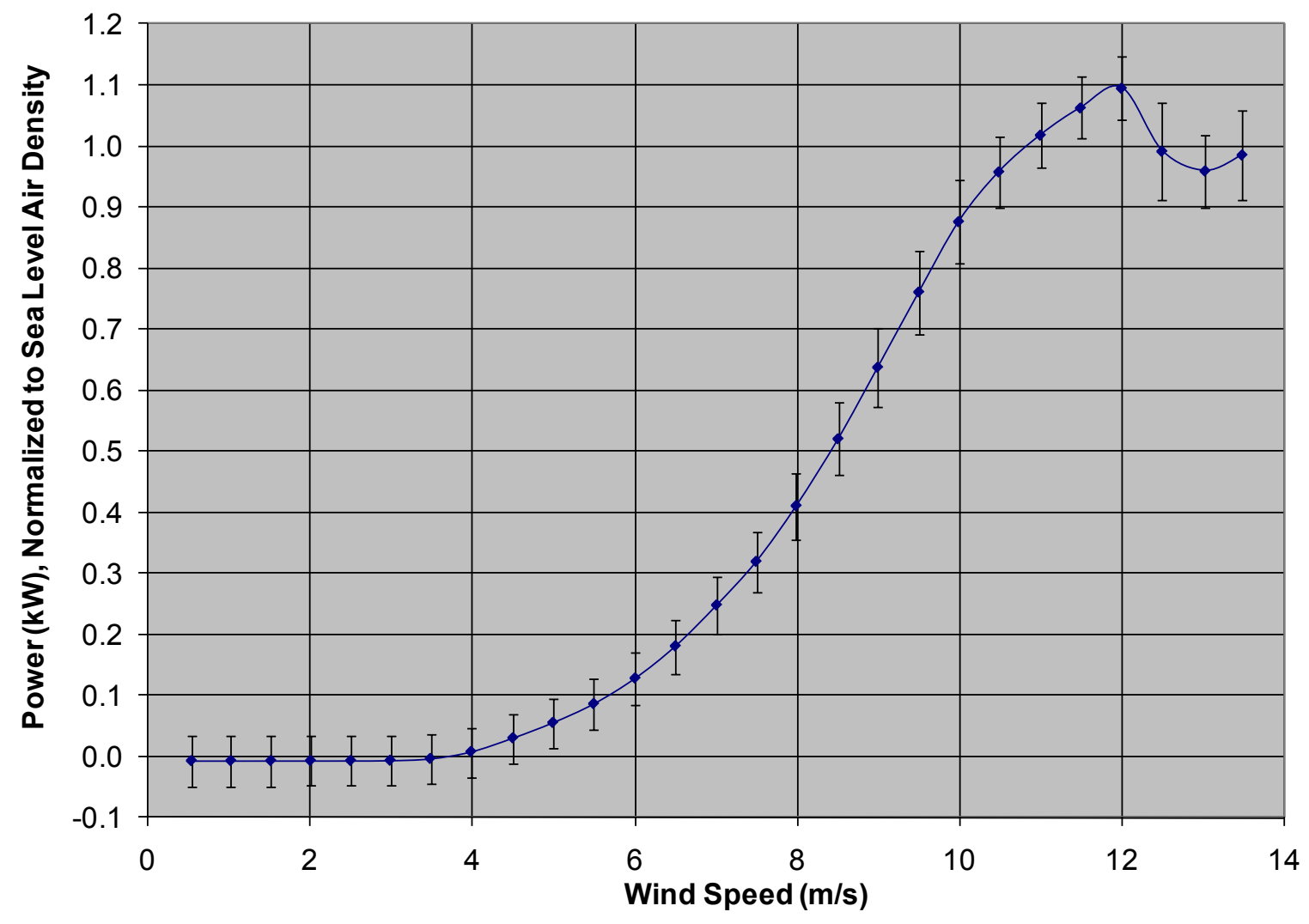

Figure 6. Power curve at sea-level density; $1.225 \mathrm{~kg} / \mathrm{m}^{3}$ for normal power production 
Figure 7 shows a plot of the binned power curve at the site average air density during the test period for normal power production.

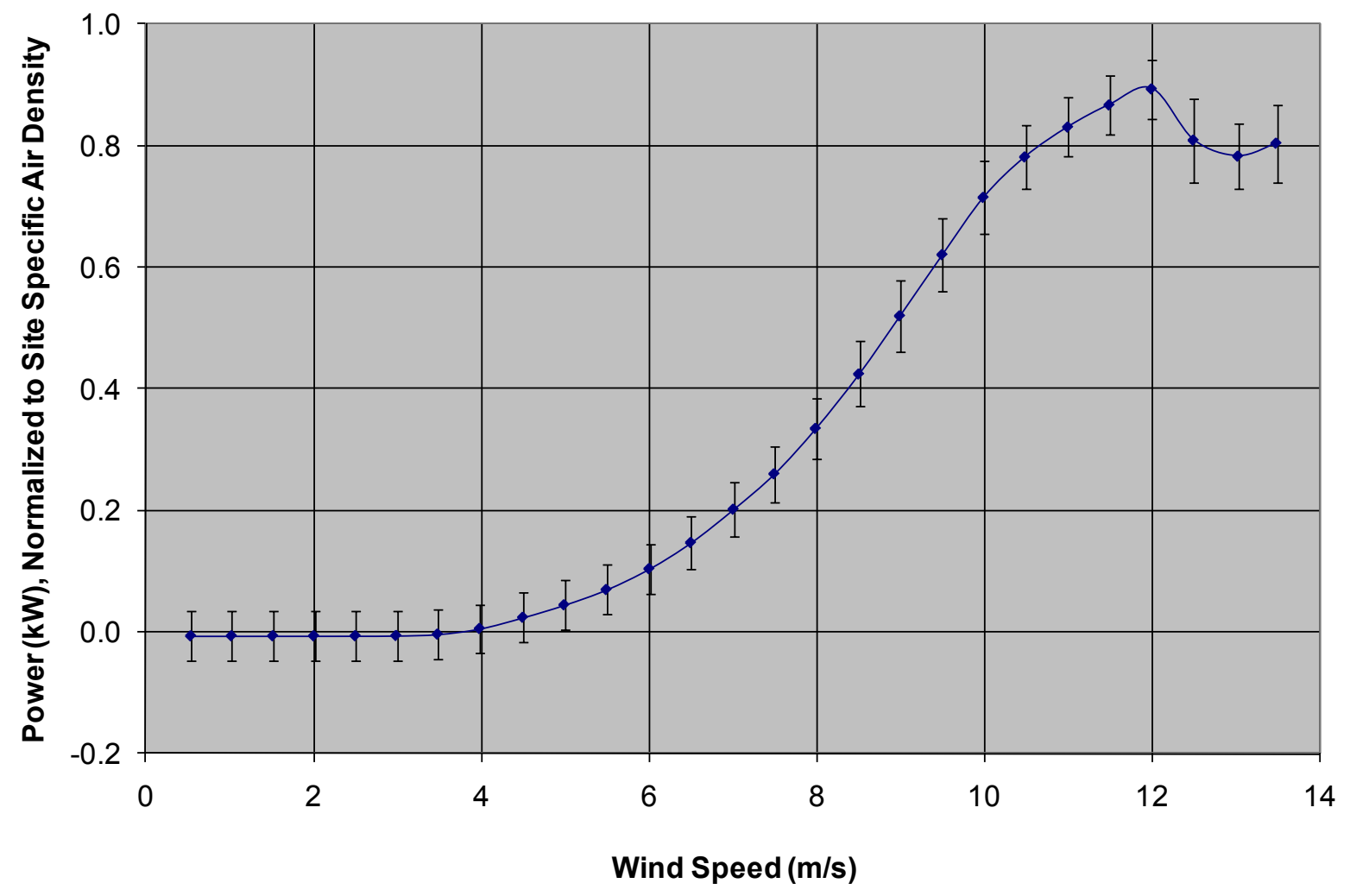

Figure 7. Power curve at site average density; $1.00 \mathrm{~kg} / \mathrm{m}^{3}$ for normal power production 
Figure 8 shows a scatter plot of statistics for normal power production.

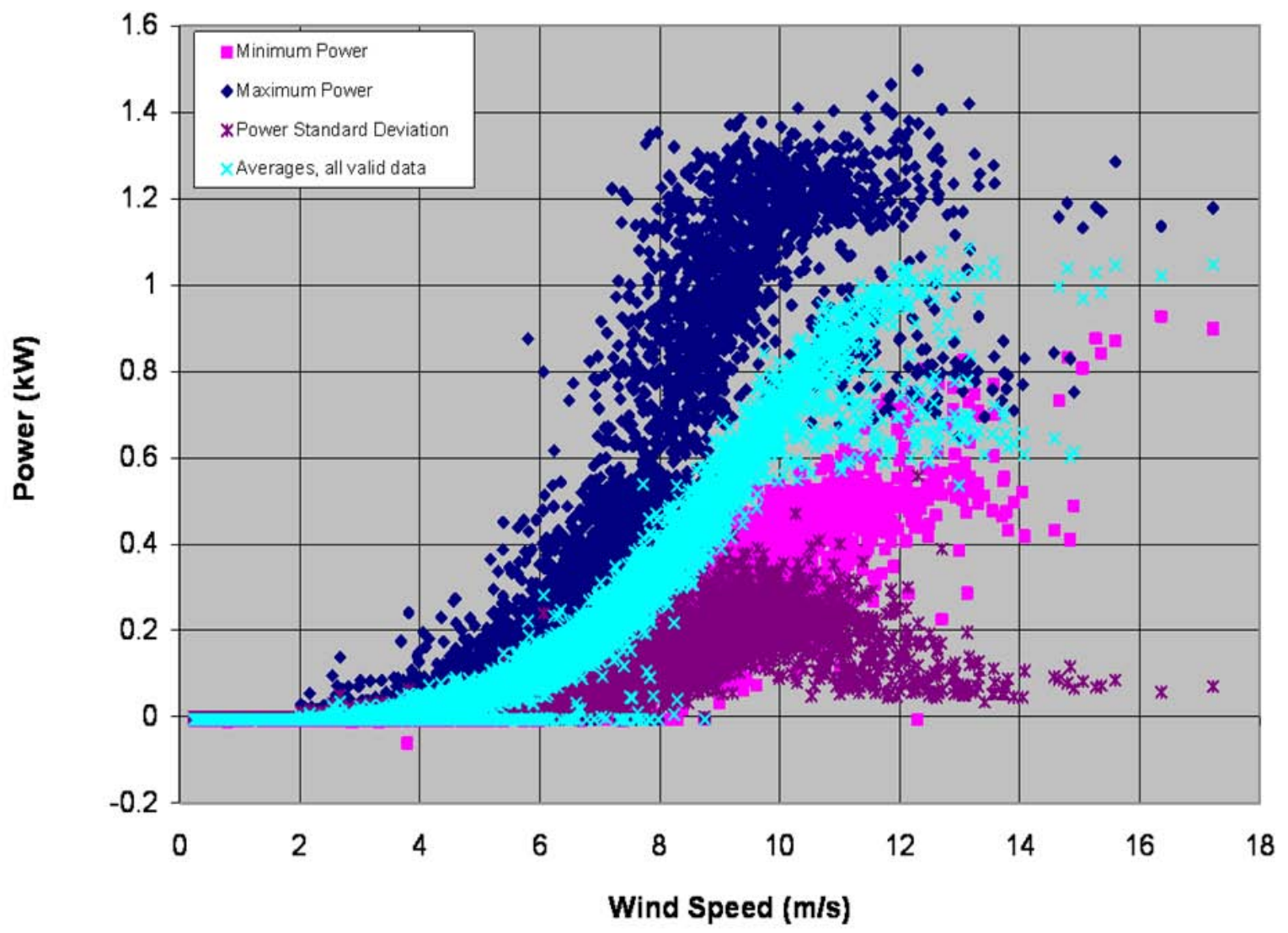

Figure 8. Scatter plot of mean, standard deviation, minimum, and maximum power data for normal power production

Multiple power curves appear at the higher wind speeds. NREL did not find the cause during testing. 
Figure 9 shows a plot of the binned coefficient of power as a function of wind speed at sea-level normalized air density for normal power production.

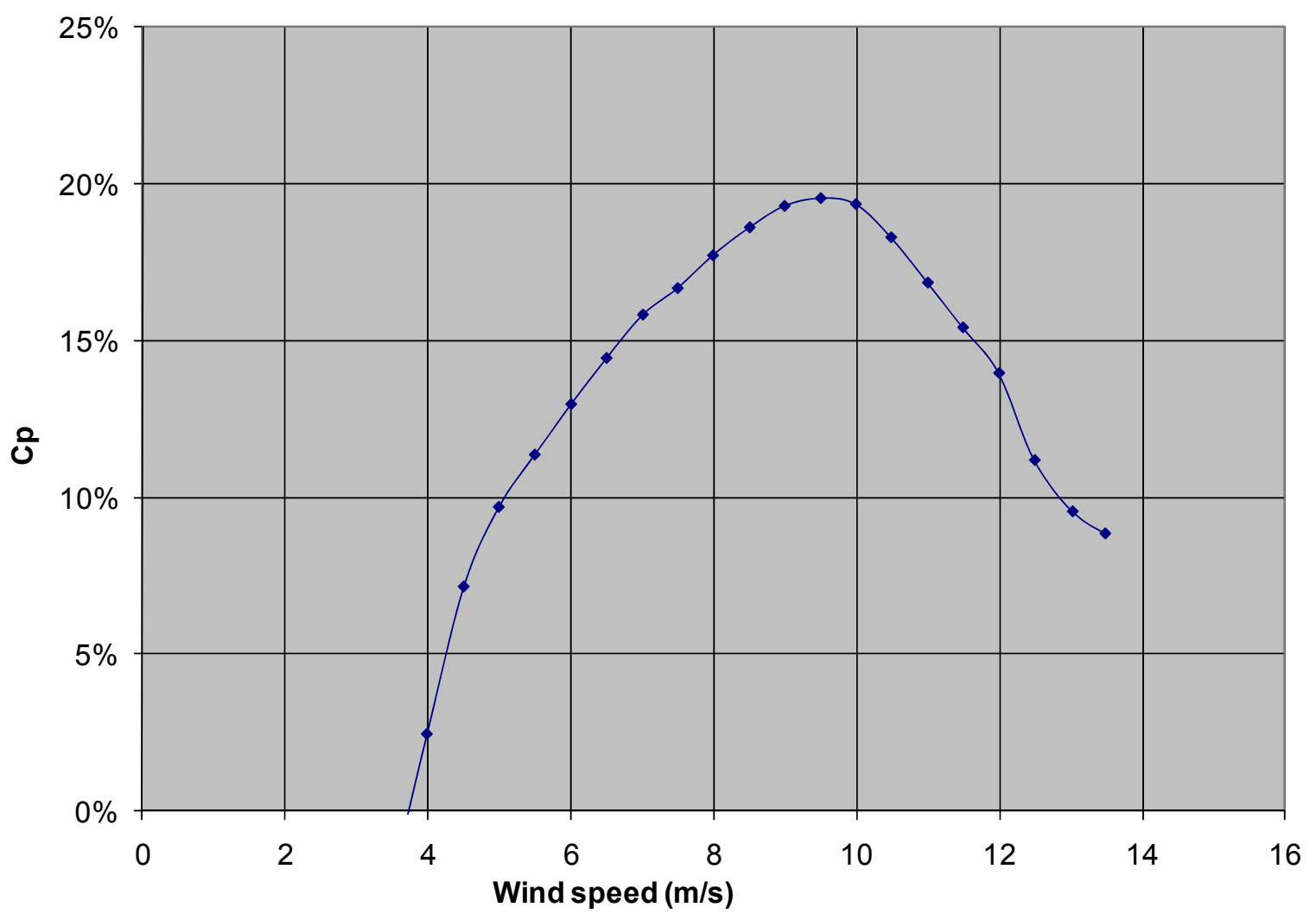

Figure 9. Coefficient of power at sea-level density; $1.225 \mathrm{~kg} / \mathrm{m}^{3}$ for normal power production 
Figure 10 shows a scatter plot and binned turbulence intensity as a function of wind speed for normal power production.

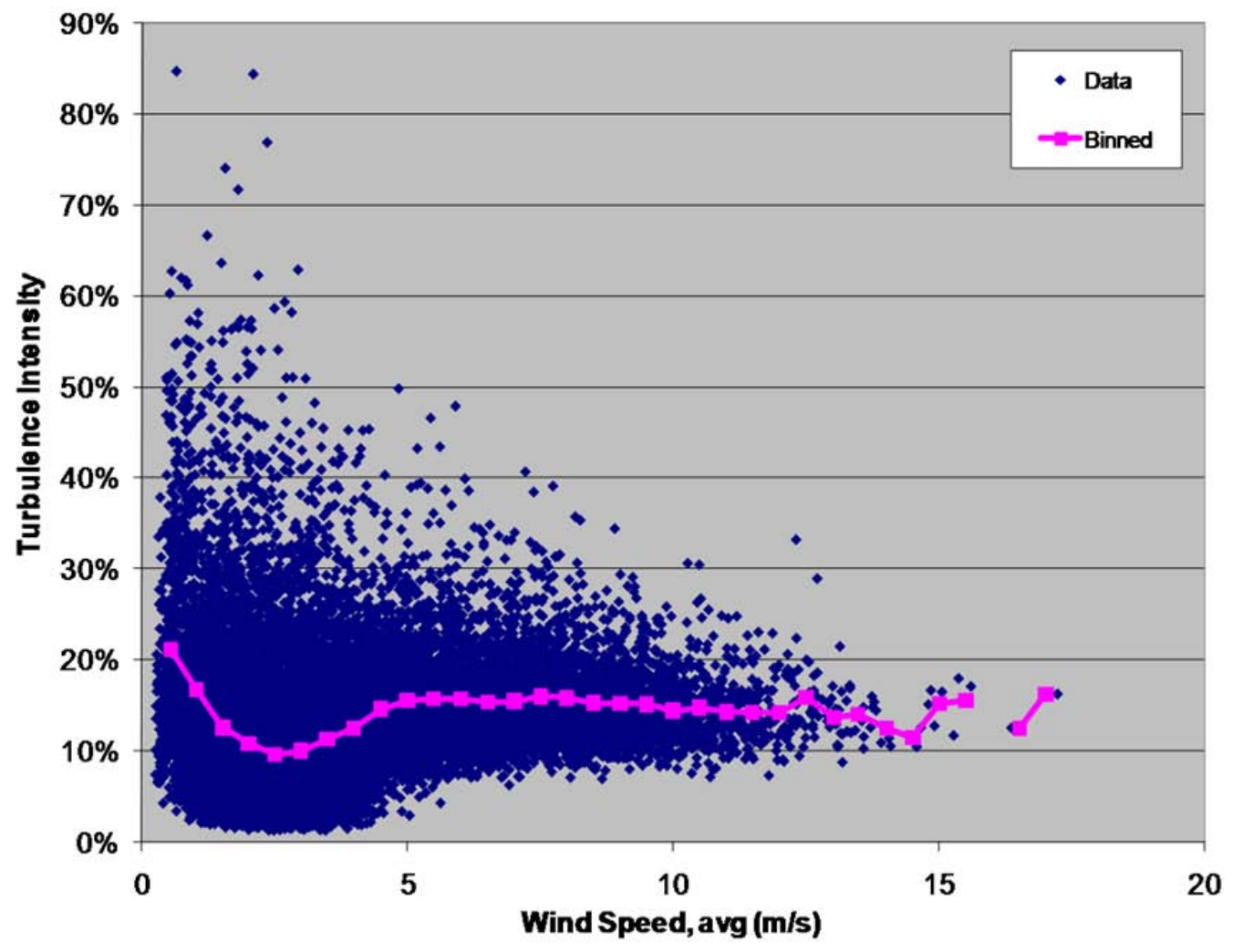

Figure 10. Wind turbulence intensity as a function of wind speed during for normal power production 
Figure 11 shows a scatter plot of wind speed and turbulence intensity as a function of wind direction for normal power production.

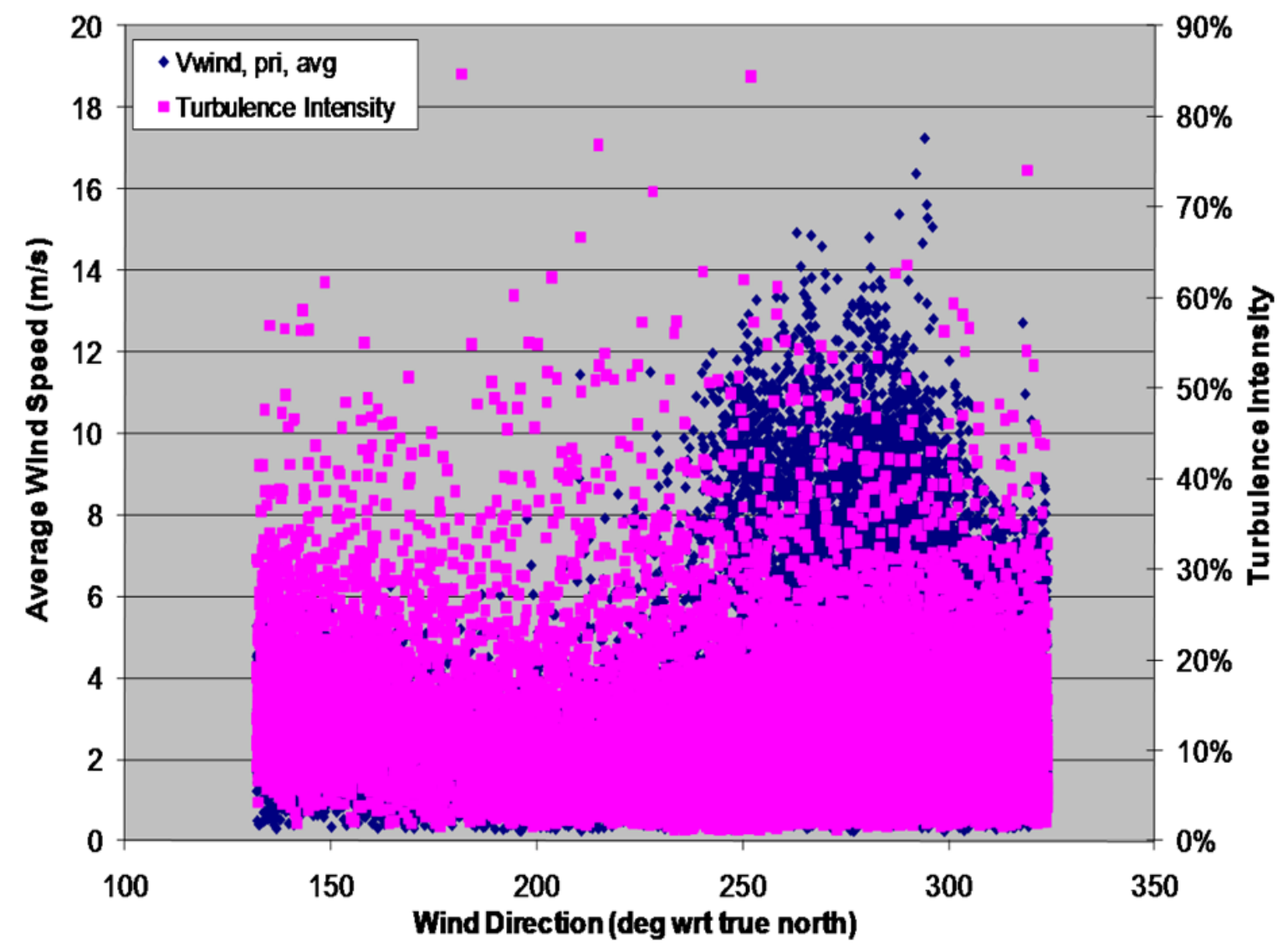

Figure 11. Wind speed and turbulence intensity as a function of wind direction during test for normal power production 
Figure 12 shows a scatter plot of binned values of rotor speed as a function of wind speed for normal power production.

\begin{tabular}{|l|l|r|r|r|r|r|r|r|r|r|r|r|r|r|r|}
\hline Wind speed & $\mathrm{m} / \mathrm{s}$ & 0.5 & 1 & 1.5 & 2 & 2.5 & 3 & 3.5 & 4 & 4.5 & 5 & 5.5 & 6 & 6.5 & 7 \\
\hline Rotor speed & $\mathrm{rpm}$ & 0 & 0 & 1 & 3 & 9 & 20 & 42 & 80 & 137 & 177 & 204 & 228 & 255 & 276 \\
\hline Wind speed & $\mathrm{m} / \mathrm{s}$ & 7.5 & 8 & 8.5 & 9 & 9.5 & 10 & 10.5 & 11 & 11.5 & 12 & 12.5 & 13 & 13.5 & 14 \\
\hline Rotor speed & $\mathrm{rpm}$ & 291 & 312 & 331 & 344 & 353 & 359 & 355 & 352 & 348 & 346 & 326 & 318 & 321 & 299 \\
\hline
\end{tabular}

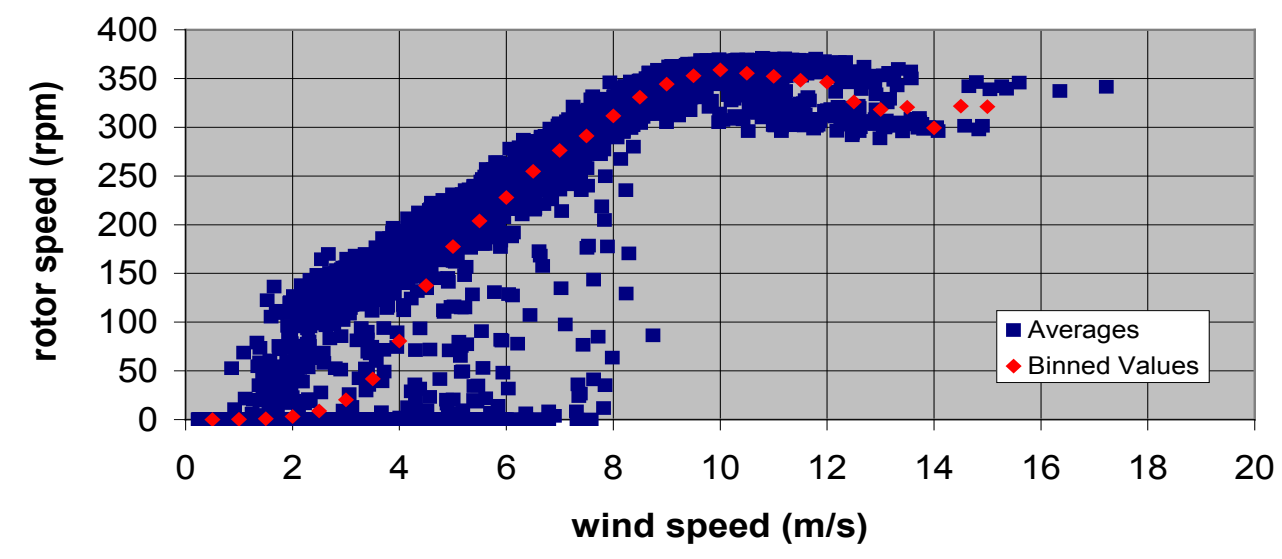

Figure 12. Rotor speed as a function of wind speed (1-minute averages) and binned values for normal power production

\subsection{Results of Power Performance Test for Optimized Power Production}

7.2.1 Tabular Results for Optimized Power Production

Table 10 through Table 13 provide the power performance test results for the optimized power production in tabular format. 
Table 10 shows the binned power performance results at sea-level normalized air density for optimized power production.

Table 10. Performance at sea-level air density; $1.225 \mathrm{~kg} / \mathrm{m}^{3}$ for optimized power production

\begin{tabular}{|c|c|c|c|c|c|c|c|}
\hline \multicolumn{8}{|c|}{ Measured power curve (database A) } \\
\hline \multicolumn{4}{|c|}{ Reference air density: $1.225 \mathrm{~kg} / \mathrm{m}^{3}$} & \multirow[b]{2}{*}{$\begin{array}{l}\text { Number of } \\
\text { 1-Minute } \\
\text { Data Sets }\end{array}$} & \multirow{2}{*}{$\begin{array}{l}\text { Category A } \\
\text { Standard } \\
\text { Uncertainty }\end{array}$} & \multirow[b]{2}{*}{$\begin{array}{l}\text { Category B } \\
\text { Standard } \\
\text { Uncertainty } \\
(\mathrm{kW})\end{array}$} & \multirow[b]{2}{*}{$\begin{array}{c}\text { Combined } \\
\text { Standard } \\
\text { Uncertainty } \\
\\
(\mathrm{kW})\end{array}$} \\
\hline$(\mathrm{m} / \mathrm{s})$ & $\begin{array}{l}\text { Wind } \\
\text { Speed } \\
(\mathrm{m} / \mathrm{s})\end{array}$ & \begin{tabular}{|c|} 
Normalized \\
Power \\
Output \\
(kW)
\end{tabular} & $\mathrm{C}_{\mathrm{p}}$ & & & & \\
\hline 3 & 2.99 & -0.01 & -0.06 & 8497 & 0.00 & 0.01 & 0.01 \\
\hline 3.5 & 3.48 & -0.01 & -0.03 & 6251 & 0.00 & 0.01 & 0.01 \\
\hline 4 & 3.98 & 0.01 & 0.02 & 3977 & 0.00 & 0.01 & 0.01 \\
\hline 4.5 & 4.48 & 0.02 & 0.06 & 2690 & 0.00 & 0.02 & 0.02 \\
\hline 5 & 4.99 & 0.05 & 0.09 & 2031 & 0.00 & 0.02 & 0.02 \\
\hline 5.5 & 5.49 & 0.08 & 0.11 & 1576 & 0.00 & 0.03 & 0.03 \\
\hline 6 & 6.00 & 0.12 & 0.12 & 1391 & 0.00 & 0.03 & 0.03 \\
\hline 6.5 & 6.48 & 0.16 & 0.13 & 1124 & 0.00 & 0.04 & 0.04 \\
\hline 7 & 6.99 & 0.22 & 0.14 & 953 & 0.00 & 0.05 & 0.05 \\
\hline 7.5 & 7.49 & 0.29 & 0.15 & 741 & 0.00 & 0.06 & 0.06 \\
\hline 8 & 7.99 & 0.37 & 0.16 & 559 & 0.00 & 0.08 & 0.08 \\
\hline 8.5 & 8.47 & 0.48 & 0.17 & 411 & 0.01 & 0.11 & 0.11 \\
\hline 9 & 8.98 & 0.60 & 0.18 & 331 & 0.01 & 0.11 & 0.11 \\
\hline 9.5 & 9.48 & 0.72 & 0.19 & 206 & 0.01 & 0.13 & 0.13 \\
\hline 10 & 10.00 & 0.86 & 0.19 & 181 & 0.01 & 0.14 & 0.14 \\
\hline 10.5 & 10.50 & 0.96 & 0.18 & 146 & 0.01 & 0.11 & 0.11 \\
\hline 11 & 10.99 & 1.08 & 0.18 & 121 & 0.01 & 0.12 & 0.12 \\
\hline 11.5 & 11.47 & 1.15 & 0.17 & 80 & 0.01 & 0.09 & 0.09 \\
\hline 12 & 12.02 & 1.24 & 0.16 & 71 & 0.02 & 0.09 & 0.09 \\
\hline 12.5 & 12.50 & 1.29 & 0.14 & 43 & 0.01 & 0.07 & 0.07 \\
\hline 13 & 13.02 & 1.32 & 0.13 & 29 & 0.01 & 0.04 & 0.04 \\
\hline 13.5 & 13.56 & 1.37 & 0.12 & 14 & 0.01 & 0.06 & 0.06 \\
\hline
\end{tabular}


Table 11 shows the binned power performance results at the site average air density for the NWTC for optimized power production.

Table 11. Performance at site average density; $0.95 \mathrm{~kg} / \mathrm{m}^{3}$ for optimized power production

\begin{tabular}{|c|c|c|c|c|c|c|c|}
\hline \multicolumn{8}{|c|}{ Measured power curve (database A) } \\
\hline \multicolumn{4}{|c|}{ Reference air density: $0.95 \mathrm{~kg} / \mathrm{m}^{3}$} & \multirow[b]{2}{*}{$\begin{array}{l}\text { Number of } \\
\text { 1-Minute } \\
\text { Data Sets }\end{array}$} & \multirow{2}{*}{$\begin{array}{l}\text { Category A } \\
\text { Standard } \\
\text { Uncertainty }\end{array}$} & \multirow[b]{2}{*}{$\begin{array}{c}\text { Category B } \\
\text { Standard } \\
\text { Uncertainty } \\
(\mathrm{kW})\end{array}$} & \multirow[b]{2}{*}{$\begin{array}{c}\text { Combined } \\
\text { Standard } \\
\text { Uncertainty } \\
(\mathrm{kW})\end{array}$} \\
\hline$(\mathrm{m} / \mathrm{s})$ & $\begin{array}{l}\text { Wind } \\
\text { Speed } \\
(\mathrm{m} / \mathrm{s})\end{array}$ & $\begin{array}{c}\text { Normalized } \\
\text { Power } \\
\text { Output } \\
(\mathrm{kW})\end{array}$ & $\mathrm{C}_{\mathrm{p}}$ & & & & \\
\hline 3 & 2.99 & -0.01 & -0.06 & 8497 & 0.00 & 0.01 & 0.01 \\
\hline 3.5 & 3.48 & 0.00 & -0.03 & 6251 & 0.00 & 0.01 & 0.01 \\
\hline 4 & 3.98 & 0.00 & 0.02 & 3977 & 0.00 & 0.01 & 0.01 \\
\hline 4.5 & 4.48 & 0.02 & 0.06 & 2690 & 0.00 & 0.02 & 0.02 \\
\hline 5 & 4.99 & 0.04 & 0.09 & 2031 & 0.00 & 0.02 & 0.02 \\
\hline 5.5 & 5.49 & 0.06 & 0.11 & 1576 & 0.00 & 0.02 & 0.02 \\
\hline 6 & 6.00 & 0.09 & 0.12 & 1391 & 0.00 & 0.03 & 0.03 \\
\hline 6.5 & 6.48 & 0.13 & 0.13 & 1124 & 0.00 & 0.03 & 0.03 \\
\hline 7 & 6.99 & 0.17 & 0.14 & 953 & 0.00 & 0.04 & 0.04 \\
\hline 7.5 & 7.49 & 0.22 & 0.15 & 741 & 0.00 & 0.05 & 0.05 \\
\hline 8 & 7.99 & 0.29 & 0.16 & 559 & 0.00 & 0.06 & 0.06 \\
\hline 8.5 & 8.47 & 0.37 & 0.17 & 411 & 0.00 & 0.08 & 0.08 \\
\hline 9 & 8.98 & 0.46 & 0.18 & 331 & 0.00 & 0.09 & 0.09 \\
\hline 9.5 & 9.48 & 0.56 & 0.19 & 206 & 0.01 & 0.10 & 0.10 \\
\hline 10 & 10.00 & 0.67 & 0.19 & 181 & 0.01 & 0.11 & 0.11 \\
\hline 10.5 & 10.50 & 0.75 & 0.18 & 146 & 0.01 & 0.08 & 0.08 \\
\hline 11 & 10.99 & 0.83 & 0.18 & 121 & 0.01 & 0.10 & 0.10 \\
\hline 11.5 & 11.47 & 0.90 & 0.17 & 80 & 0.01 & 0.07 & 0.07 \\
\hline 12 & 12.02 & 0.96 & 0.16 & 71 & 0.01 & 0.07 & 0.07 \\
\hline 12.5 & 12.50 & 1.00 & 0.14 & 43 & 0.01 & 0.05 & 0.05 \\
\hline 13 & 13.02 & 1.02 & 0.13 & 29 & 0.01 & 0.03 & 0.03 \\
\hline 13.5 & 13.56 & 1.06 & 0.12 & 14 & 0.01 & 0.05 & 0.05 \\
\hline
\end{tabular}


Table 12 shows the annual energy production at sea-level normalized air density for optimized power production. Table 13 shows the annual energy production at the site average air density at the NWTC for optimized power production.

Table 12. Annual energy production (AEP) at sea-level density; $1.225 \mathrm{~kg} / \mathrm{m}^{3}$ for optimized power production

\begin{tabular}{|c|c|c|c|c|c|}
\hline \multicolumn{6}{|c|}{ Estimated annual energy production, database A (all valid data) } \\
\hline & $\begin{array}{l}\text { Reference air density: } \\
\text { Cut-out wind speed: }\end{array}$ & $\begin{array}{l}1.225 \\
20.00\end{array}$ & $\begin{array}{l}\mathrm{kg} / \mathrm{m}^{\wedge} 3 \\
\mathrm{~m} / \mathrm{s}\end{array}$ & & \\
\hline \multirow{2}{*}{$\begin{array}{c}\text { Hub height } \\
\text { annual average } \\
\text { wind speed } \\
\text { (Ravleigh) } \\
\mathrm{m} / \mathrm{s}\end{array}$} & \multirow{2}{*}{$\begin{array}{c}\text { AEP-measured } \\
\text { kWh }\end{array}$} & \multicolumn{2}{|c|}{$\begin{array}{l}\text { Standard Uncertainty in AEP- } \\
\text { measured }\end{array}$} & \multirow{2}{*}{$\begin{array}{c}\text { AEP- } \\
\text { extrapolated } \\
\text { kWh }\end{array}$} & \multirow{2}{*}{$\begin{array}{c}\text { Complete if AEP } \\
\text { measured is at least } \\
95 \% \text { of AEP } \\
\text { extrapolated }\end{array}$} \\
\hline & & kWh & $\%$ & & \\
\hline 4 & 569 & 229 & $40 \%$ & 571 & Complete \\
\hline 5 & 1,309 & 332 & $25 \%$ & 1,347 & Complete \\
\hline 6 & 2,127 & 416 & $20 \%$ & 2,343 & Incomplete \\
\hline 7 & 2,786 & 463 & $17 \%$ & 3,397 & Incomplete \\
\hline 8 & 3,192 & 476 & $15 \%$ & 4,361 & Incomplete \\
\hline 9 & 3,367 & 467 & $14 \%$ & 5,139 & Incomplete \\
\hline 10 & 3,376 & 444 & $13 \%$ & 5,690 & Incomplete \\
\hline 11 & 3,277 & 414 & $13 \%$ & 6.023 & Incomplete \\
\hline \multicolumn{6}{|c|}{$\begin{array}{l}\text { AEP measured assumes zero power between highest bin and cutout } \\
\text { AEP extrapolated assumes power in last bin between last bin and cutout }\end{array}$} \\
\hline
\end{tabular}

Table 13. Annual energy production at site average density; $0.95 \mathrm{~kg} / \mathrm{m}^{3}$ for optimized power production

\begin{tabular}{|c|c|c|c|c|c|}
\hline \multicolumn{6}{|c|}{ Estimated annual energy production, database A (all valid data) } \\
\hline \multicolumn{2}{|c|}{$\begin{array}{l}\text { Reference air density: } \\
\text { Cut-out wind speed: }\end{array}$} & $\begin{array}{c}0.95 \\
25.00 \\
\end{array}$ & $\begin{array}{l}\mathrm{kg} / \mathrm{m}^{\wedge} 3 \\
\mathrm{~m} / \mathrm{s}\end{array}$ & & \\
\hline \multirow{2}{*}{$\begin{array}{c}\text { Hub height } \\
\text { annual } \\
\text { average wind } \\
\text { speed } \\
\text { (Rayleigh) } \\
\mathrm{m} / \mathrm{s}\end{array}$} & \multirow{2}{*}{$\begin{array}{c}\text { AEP-measured } \\
\text { MWh }\end{array}$} & \multicolumn{2}{|c|}{$\begin{array}{c}\text { Standard Uncertainty in AEP- } \\
\text { measured }\end{array}$} & \multirow{2}{*}{$\begin{array}{c}\text { AEP- } \\
\text { extrapolated } \\
M W h\end{array}$} & \multirow{2}{*}{$\begin{array}{c}\text { Complete if AEP } \\
\text { measured is at least } \\
95 \% \text { of AEP } \\
\text { extrapolated }\end{array}$} \\
\hline & & MWh & $\%$ & & \\
\hline 4 & 442 & 194 & $44 \%$ & 443 & Complete \\
\hline 5 & 1,015 & 271 & $27 \%$ & 1,044 & Complete \\
\hline 6 & 1,650 & 334 & $20 \%$ & 1,817 & Incomplete \\
\hline 7 & 2,160 & 368 & $17 \%$ & 2,634 & Incomplete \\
\hline 8 & 2,475 & 377 & $15 \%$ & 3,382 & Incomplete \\
\hline 9 & 2,612 & 369 & $14 \%$ & 3,985 & Incomplete \\
\hline 10 & 2,618 & 350 & $13 \%$ & 4,413 & Incomplete \\
\hline 11 & 2,542 & 327 & $13 \%$ & 4,671 & Incomplete \\
\hline & $\begin{array}{l}\text { P measured a } \\
\text { extrapolated a }\end{array}$ & es zero & between $h$ & bin and cu & ut \\
\hline
\end{tabular}




\subsubsection{Graphical Results for Power-Optimized Configuration}

Figure 13 through Figure 19 show the results of the power performance test for optimized power production in graphical format. Figure 13 shows a plot of the binned power curve normalized to sea-level air density of optimized power production.

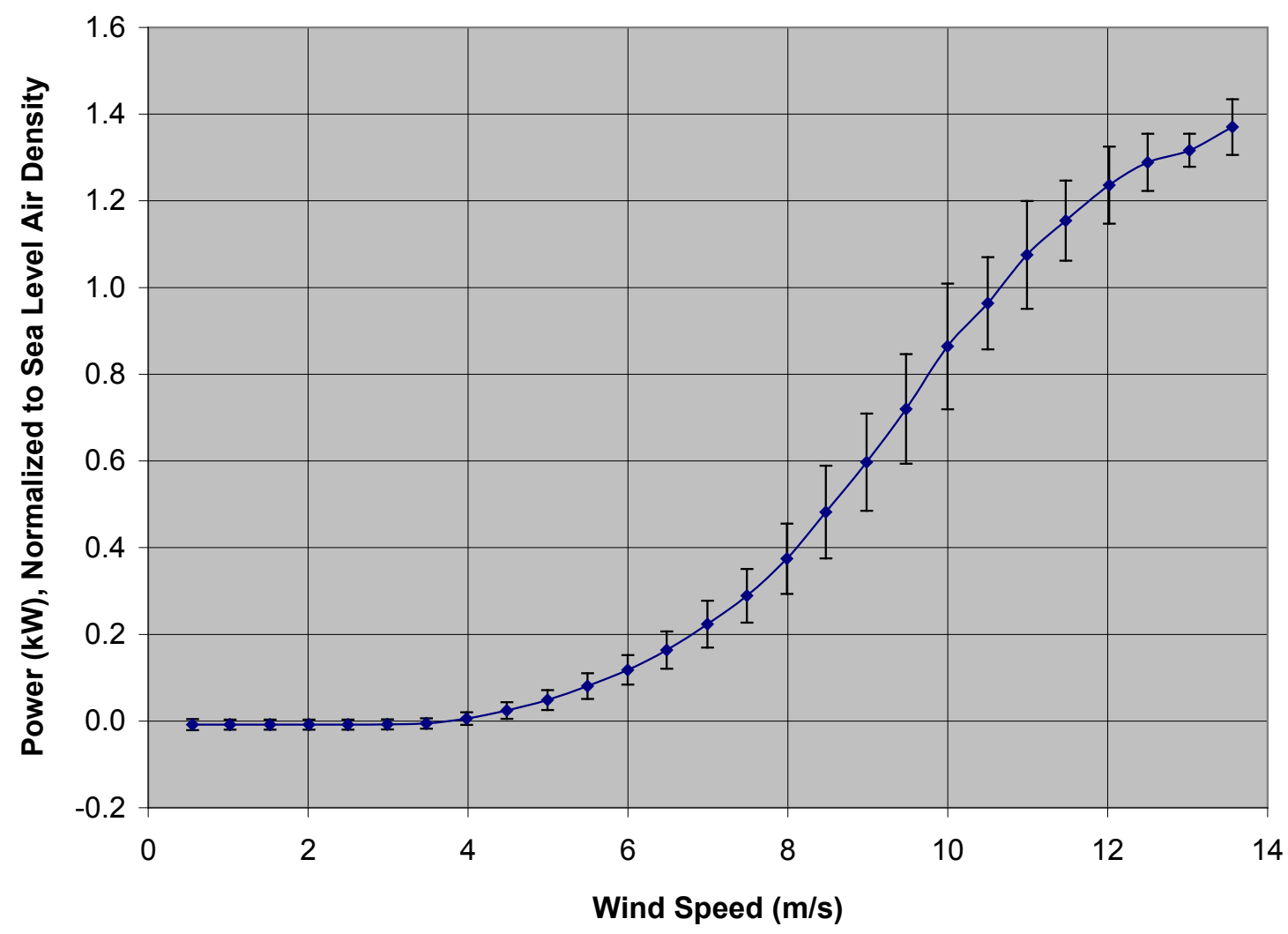

Figure 13. Power curve at sea-level density; $1.225 \mathrm{~kg} / \mathrm{m}^{3}$ for optimized power production 
Figure 14 shows a plot of the binned power curve at the site average air density for the NWTC for optimized power production.

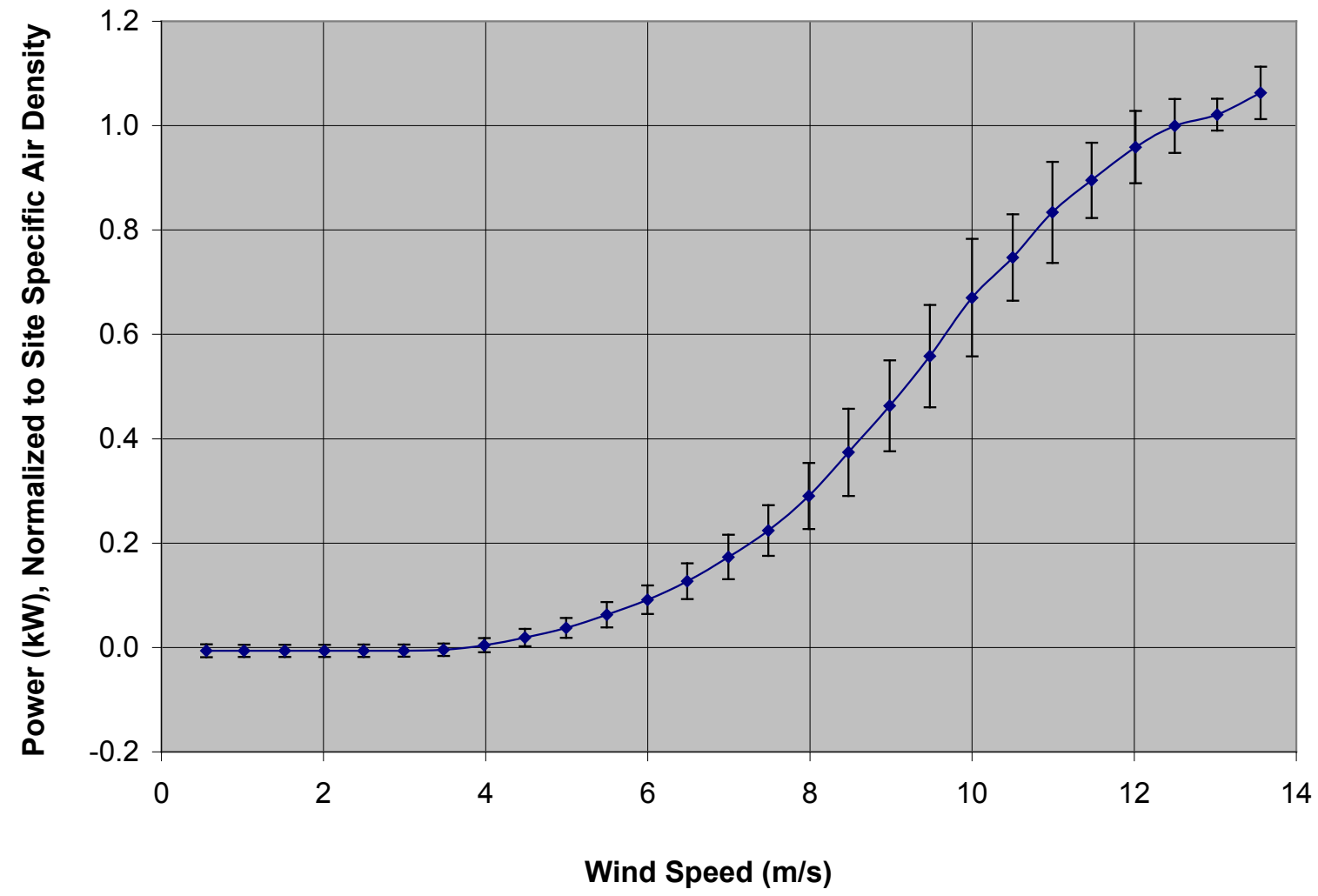

Figure 14. Power curve at site average density; $0.95 \mathrm{~kg} / \mathrm{m}^{3}$ for optimized power production 
Figure 15 shows a scatter plot of statistics for optimized power production.

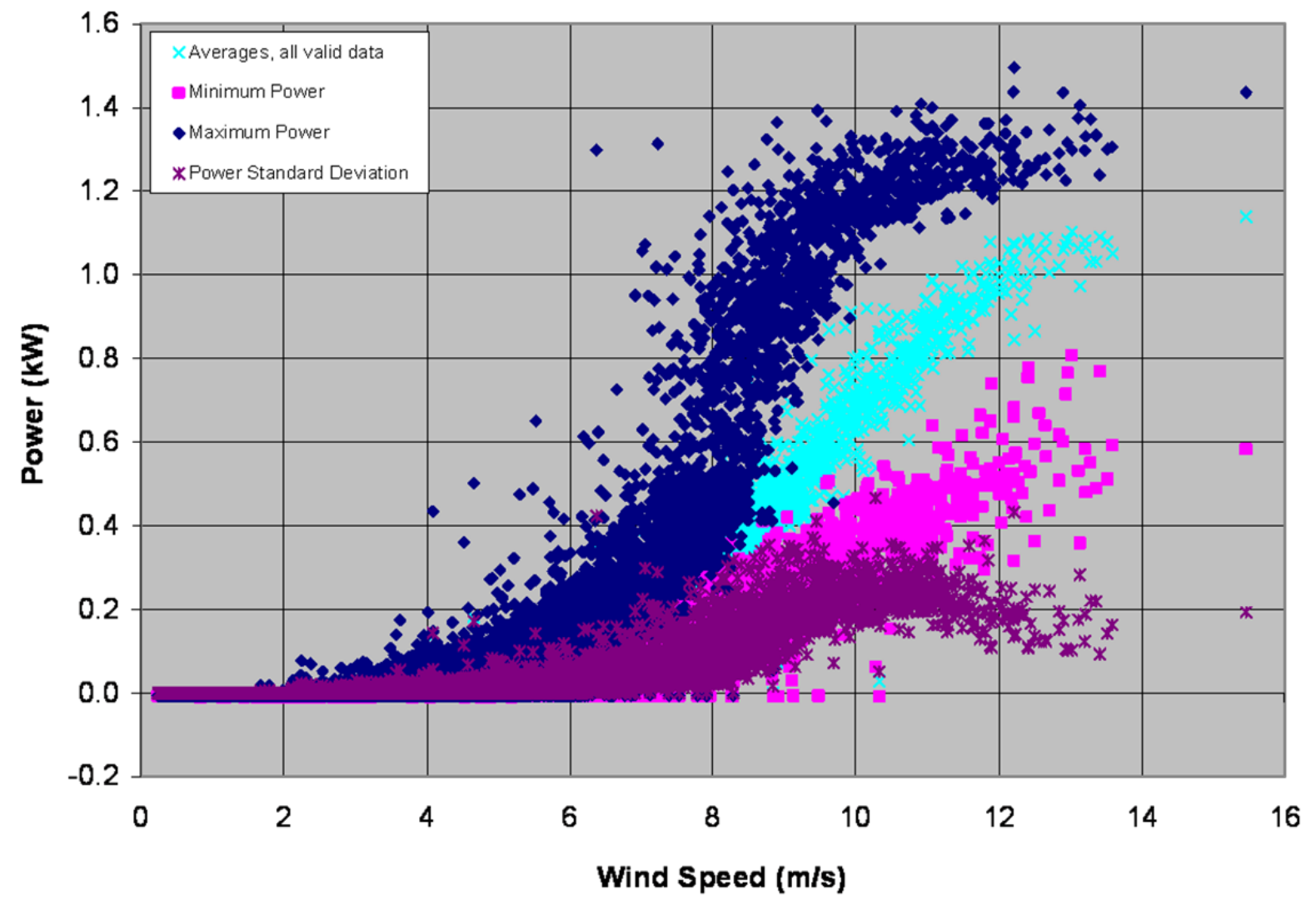

Figure 15. Scatter plot of mean, standard deviation, minimum, and maximum power data for optimized power production 
Figure 16 shows a plot of the binned coefficient of power as a function of wind speed at sealevel normalized air density for optimized power production.

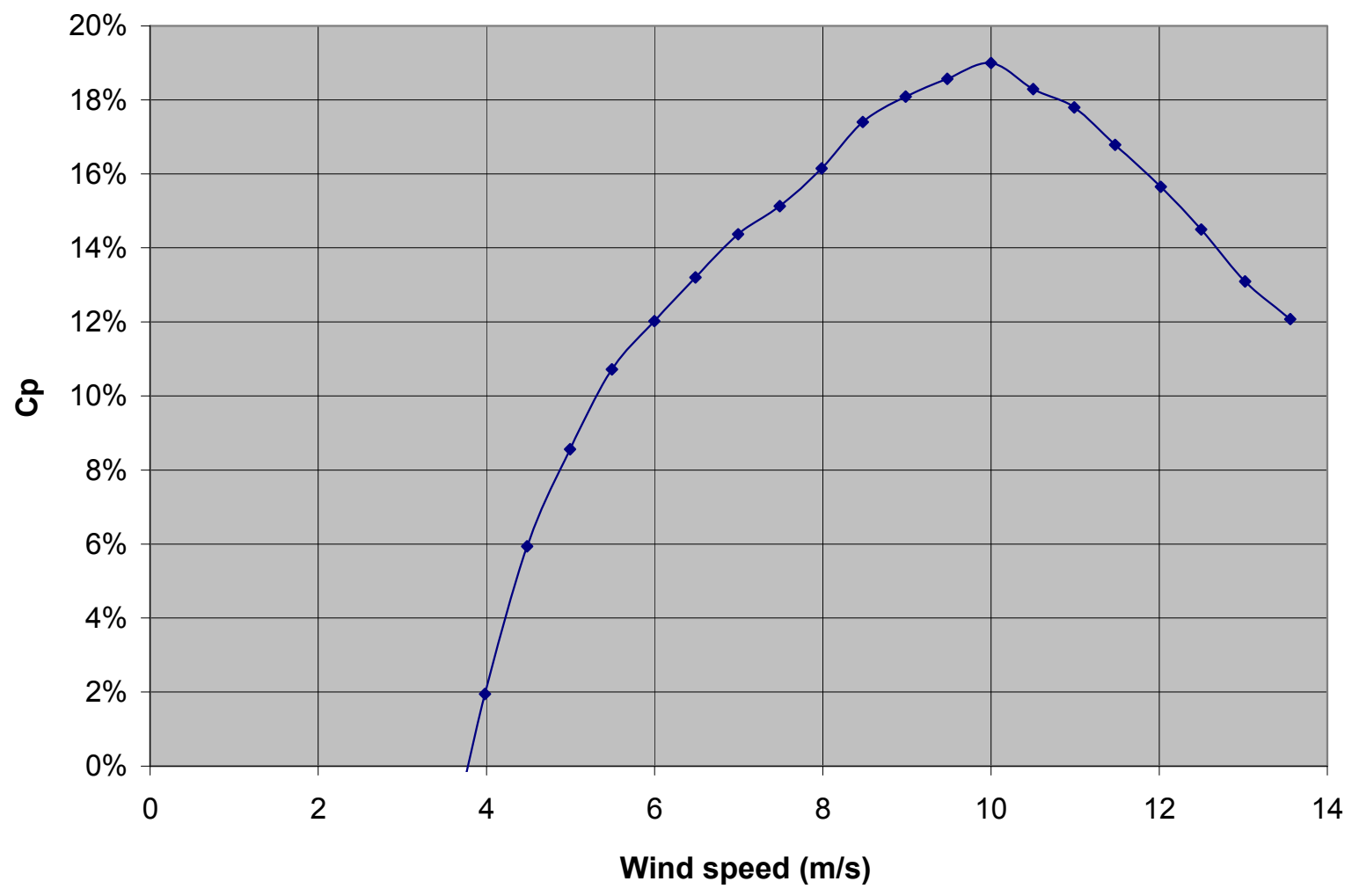

Figure 16. Coefficient of power at sea level density; $1.225 \mathrm{~kg} / \mathrm{m}^{3}$ for optimized power production 
Figure 17 shows a scatter plot and binned turbulence intensity as a function of wind speed for optimized power production.

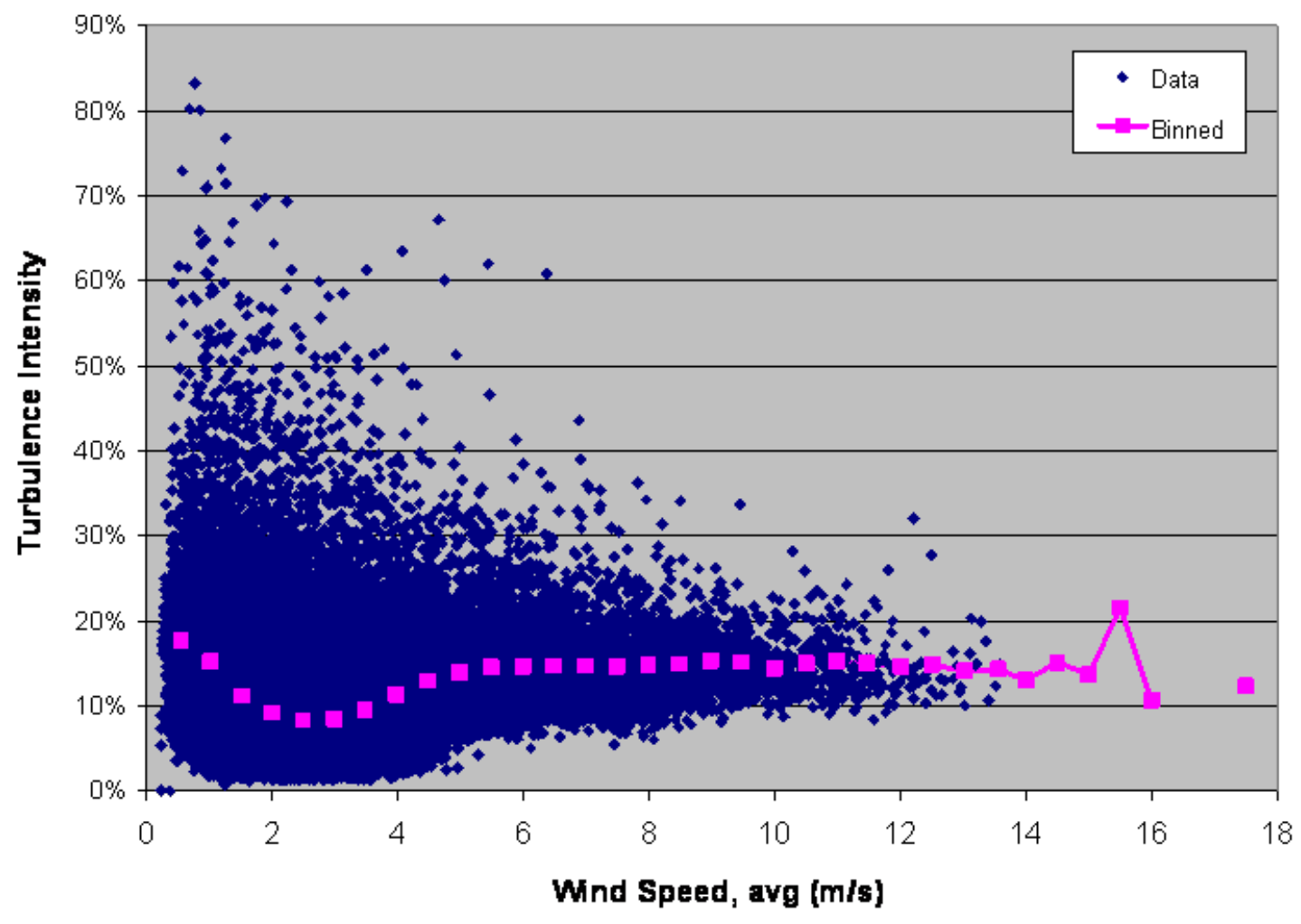

Figure 17. Wind turbulence intensity as a function of wind speed during the test for optimized power production 
Figure 18 shows a scatter plot of wind speed and turbulence intensity as a function of wind direction for optimized power production.

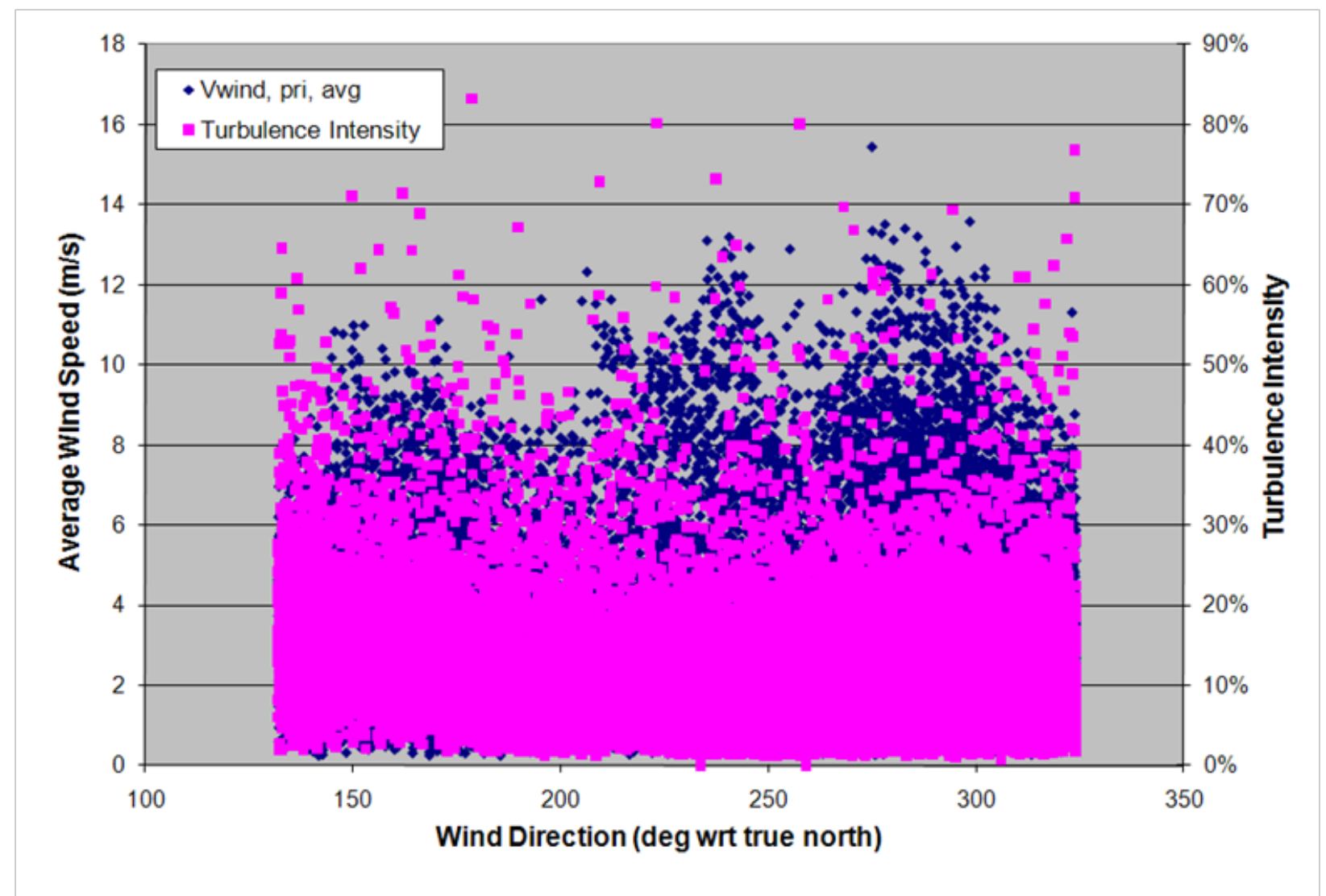

Figure 18. Wind speed and turbulence intensity as a function of wind direction during the test for optimized power production 
Figure 19 shows a scatter plot and binned values of rotor speed as a function of wind speed for optimized power production.

\begin{tabular}{|c|c|c|c|c|c|c|c|c|c|c|c|c|c|c|c|}
\hline \begin{tabular}{|l|} 
Wind speed \\
\end{tabular} & $\mathrm{m} / \mathrm{s}$ & 0.5 & 1 & 1.5 & 2 & 25 & 3 & 3.5 & 4 & 4.5 & 5 & 5.5 & 6 & 6.5 & 7 \\
\hline Rotor speed & rpm & $\mathbf{0}$ & 0 & 1 & 2 & 8 & 21 & 43 & 80 & 125 & 164 & 199 & 227 & 253 & 279 \\
\hline Wind speed & $\mathrm{m} / \mathrm{s}$ & 7.5 & 8 & 8.5 & 9 & 9.5 & 10 & 10.5 & 11 & 11.5 & 12 & 125 & 13 & 13.5 & 14 \\
\hline Rotor speed & rpm & 299 & 320 & 337 & 350 & 360 & 367 & 369 & 373 & 374 & 371 & 373 & 369 & 370 & 371 \\
\hline
\end{tabular}

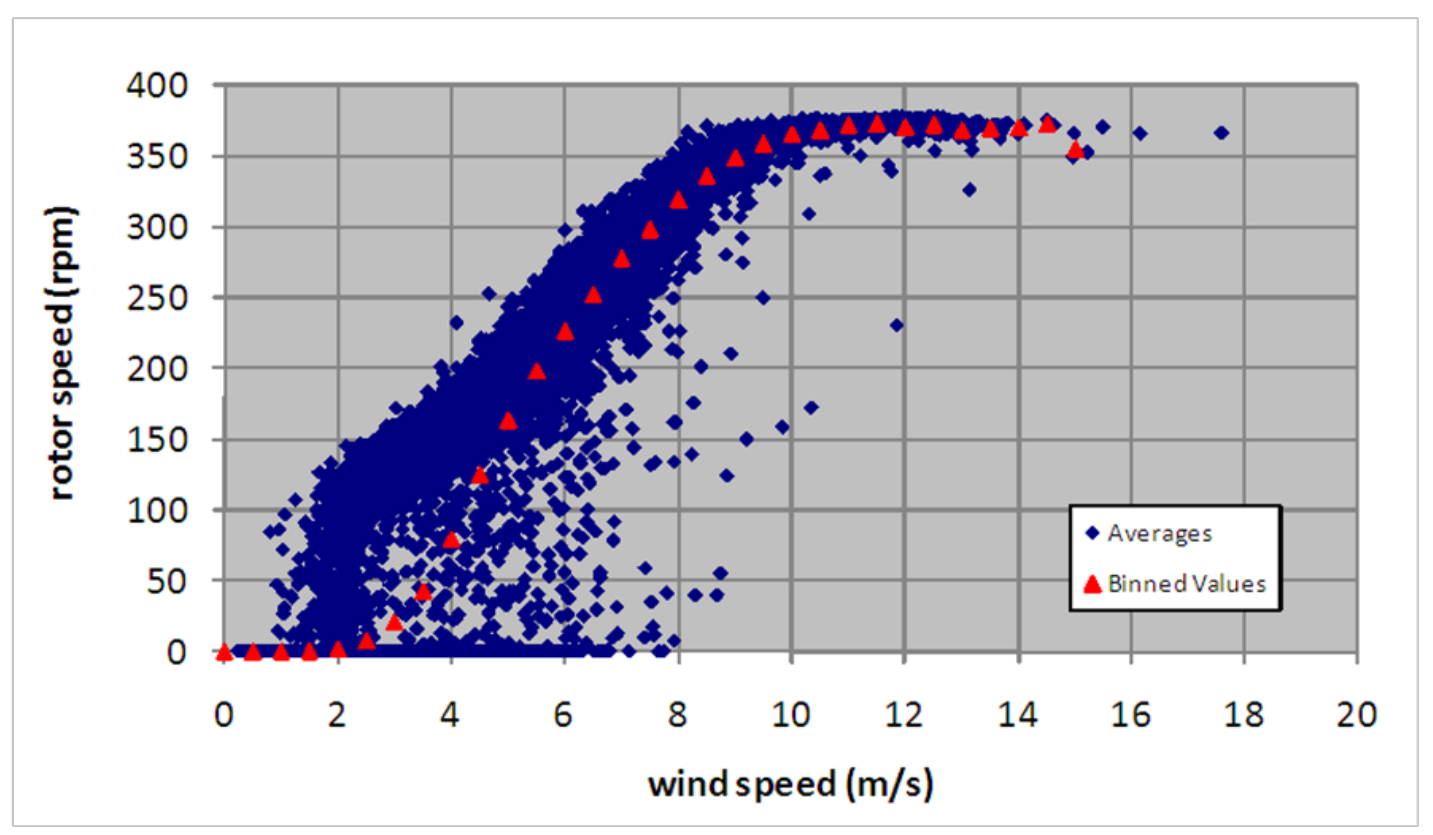

Figure 19. Rotor speed as a function of wind speed (1-minute averages) and binned values for optimized power production 


\section{Deviations and Exceptions}

\subsection{Deviations from the Standard}

1. The current transformers are not complaint with IEC 60044-1, but do exceed the minimum accuracy required by the Standard.

2. For both turbine configurations, the $14 \mathrm{~m} / \mathrm{s}$ wind speed bin was not filled as required in Annex $\mathrm{H}$.

\subsection{Exceptions to NWTC-CT Quality Assurance System}

The data acquisition modules were used beyond the calibration due date. The modules were post-test calibrated and found in compliance with the specifications. The post-test calibration sheets are included in Appendix B. 
A. Appendix - Pictures of the Test Site from the Turbine Base 


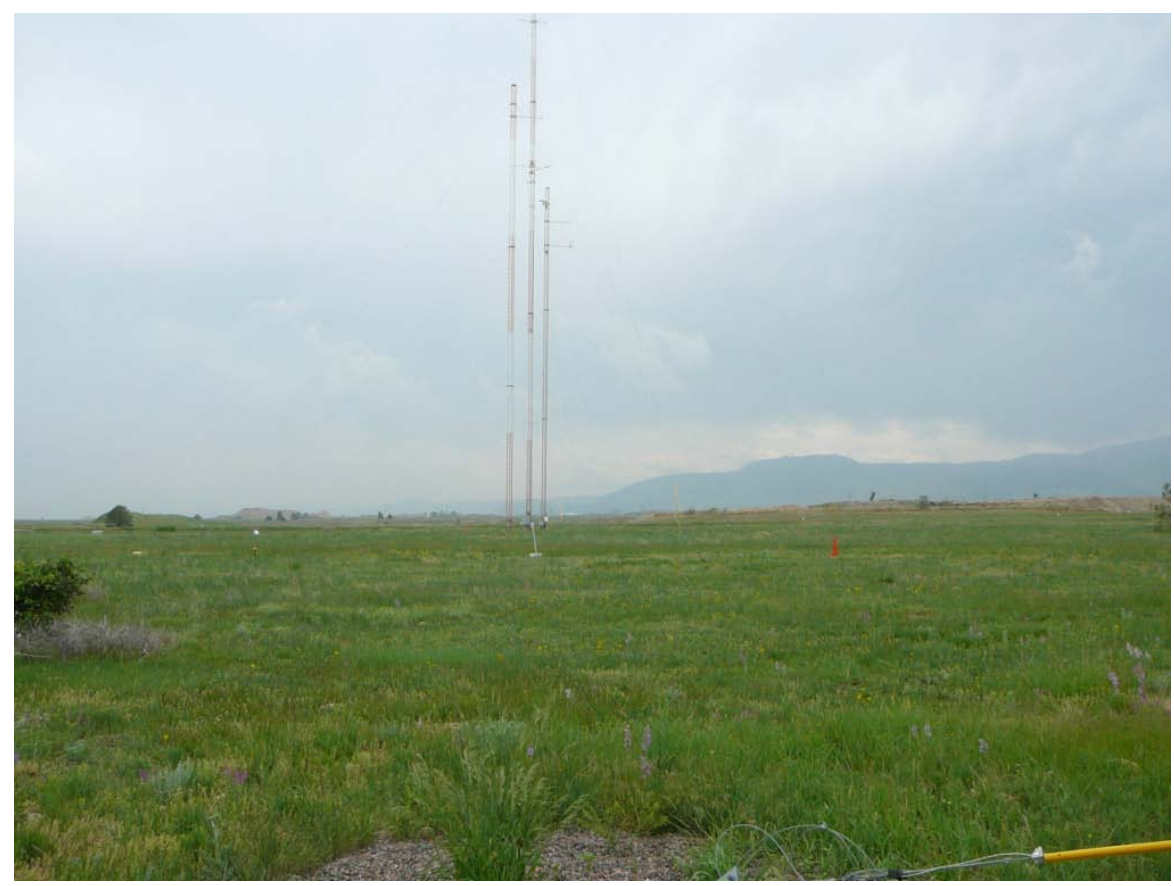

Figure A.1. South-southwest

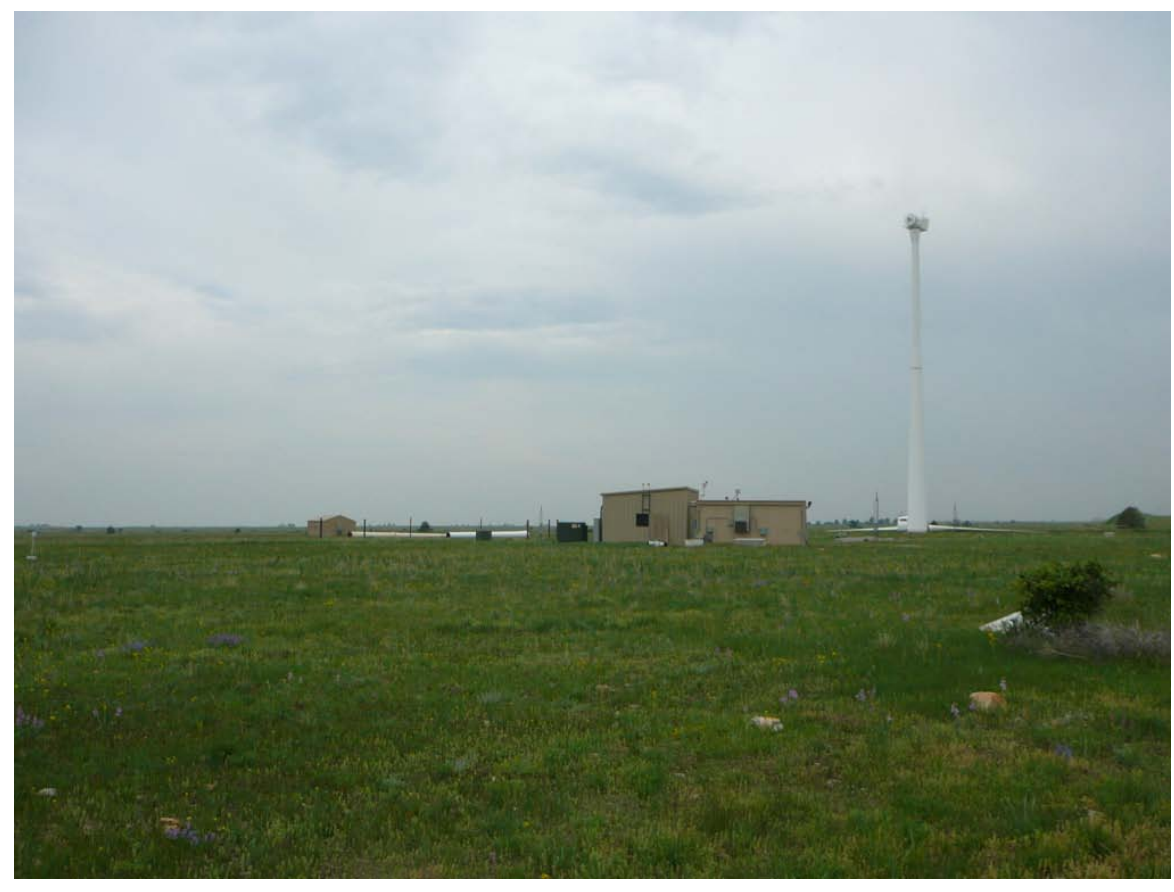

Figure A.2. South-southeast 


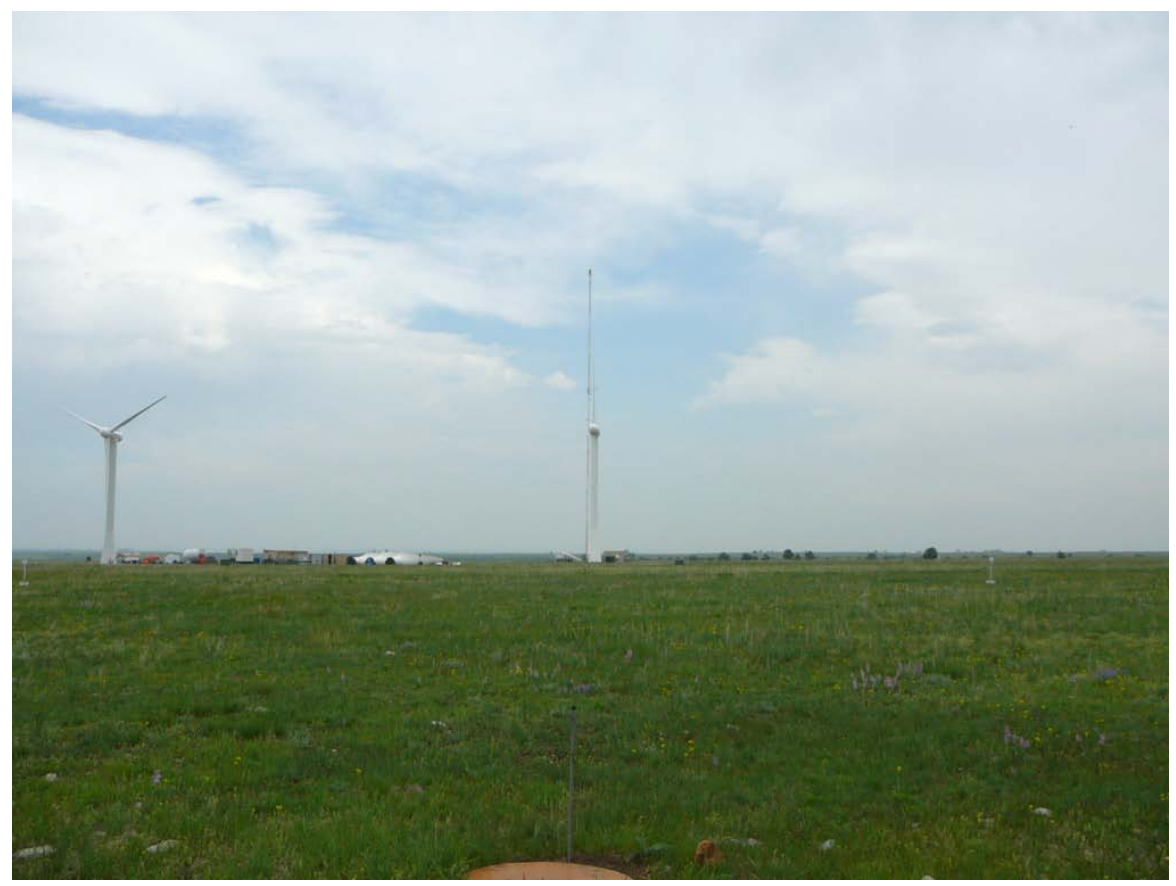

Figure A.3. East-southeast

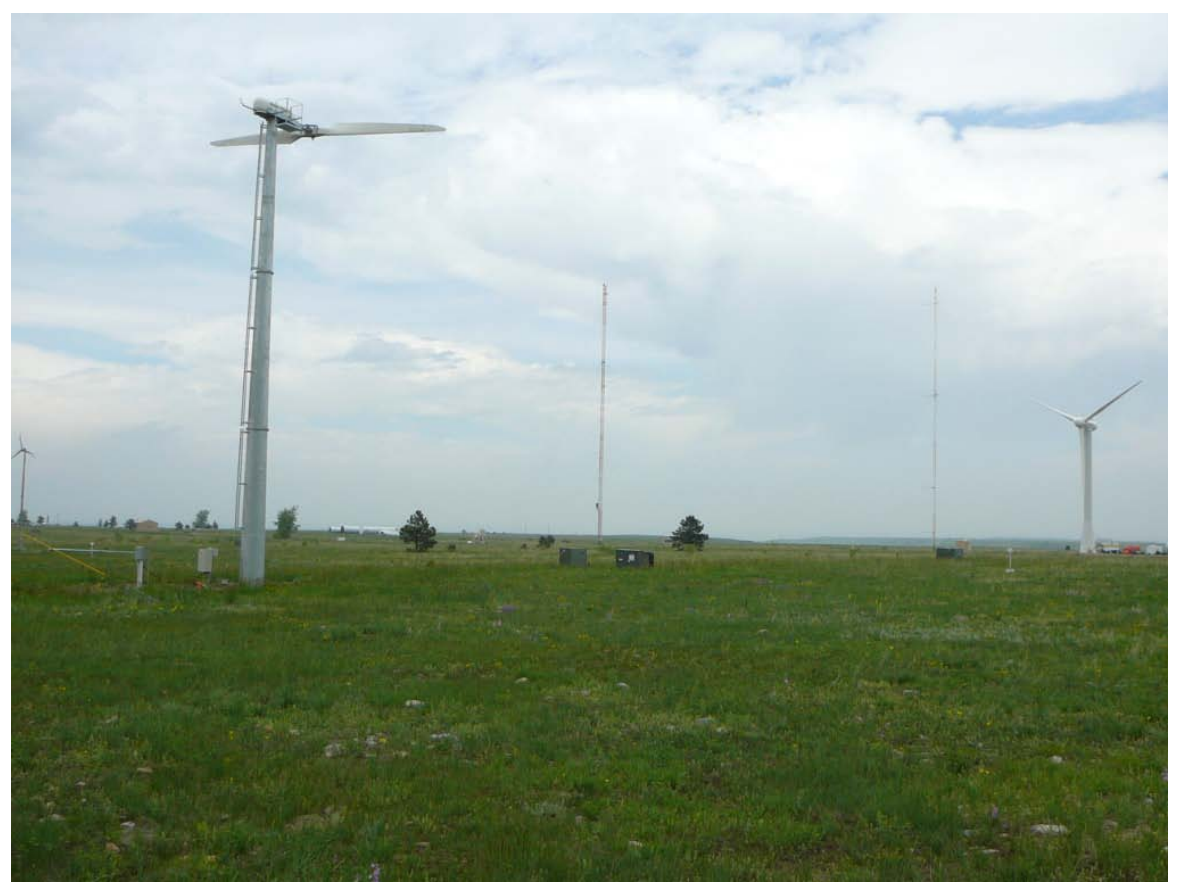

Figure A.4. East-northeast 


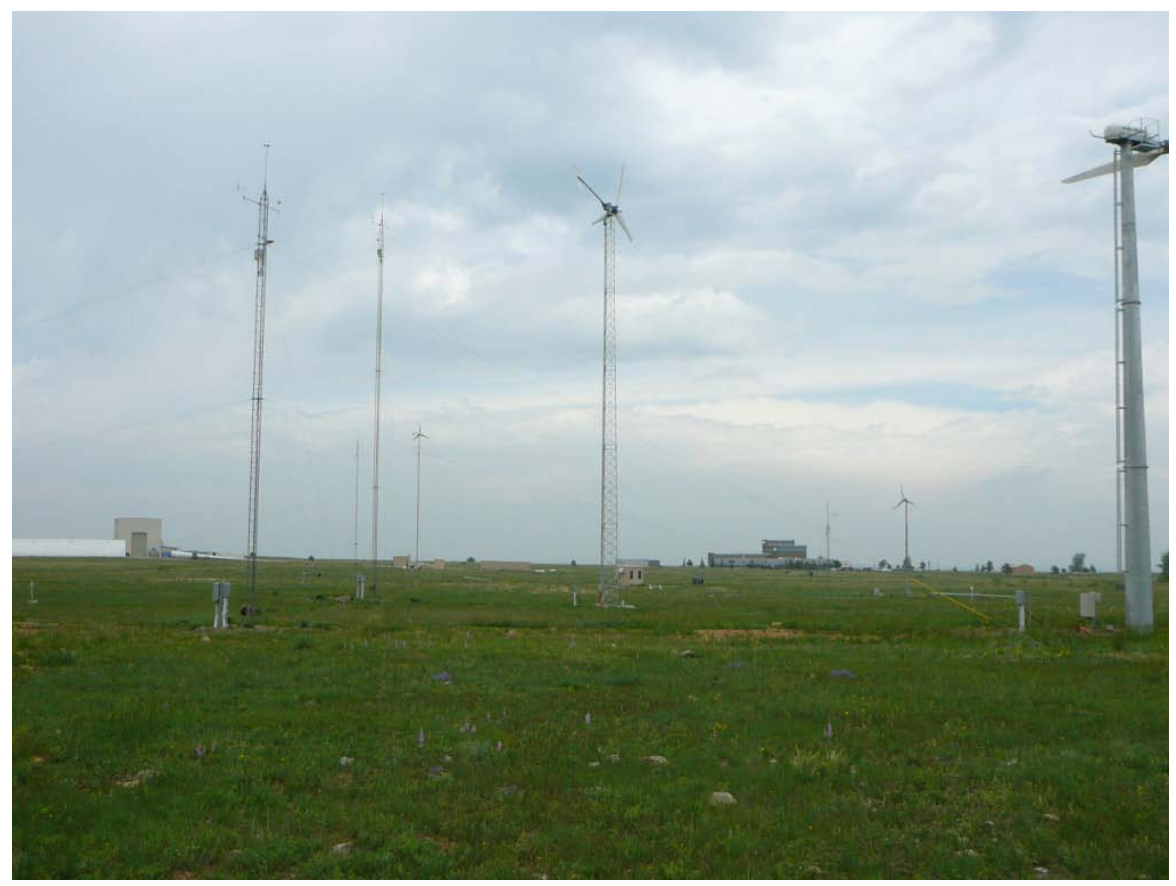

Figure A.5. North-northeast

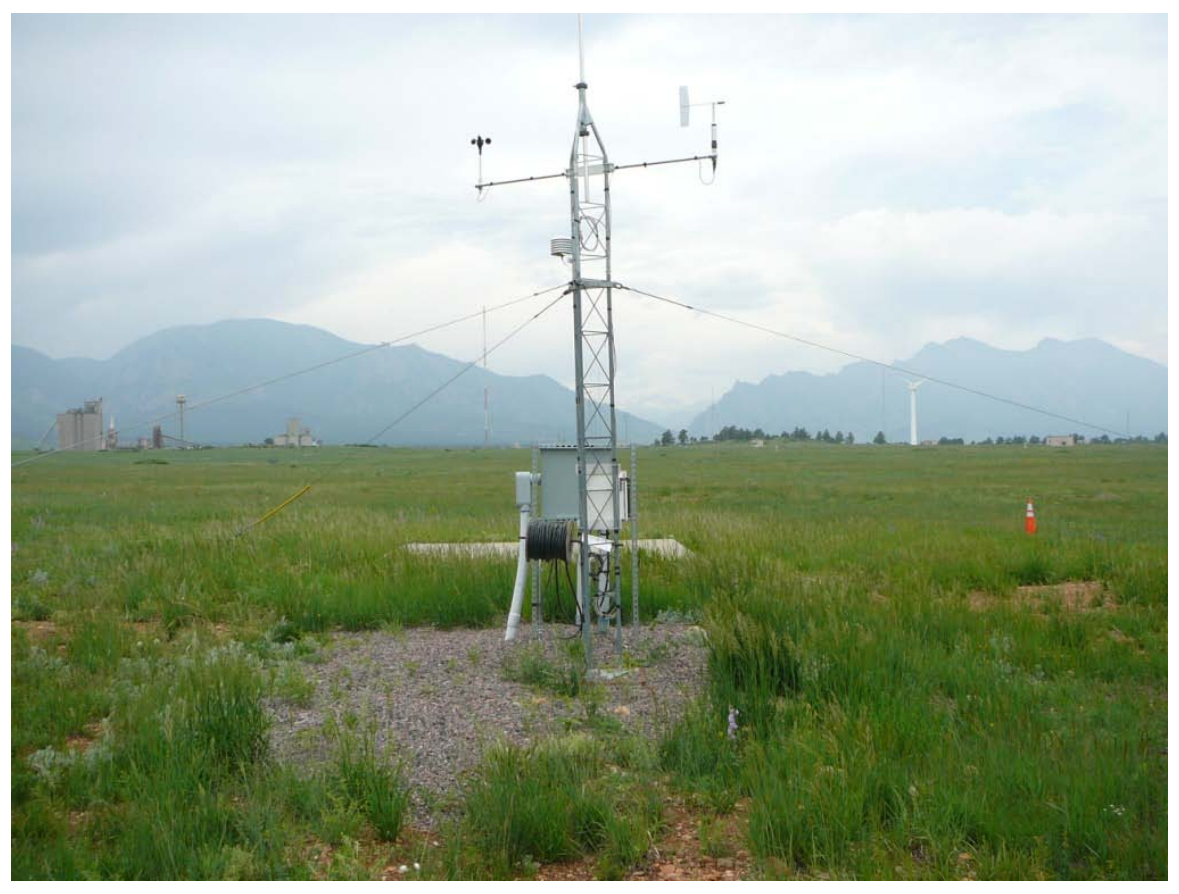

Figure A.6. Northwest 


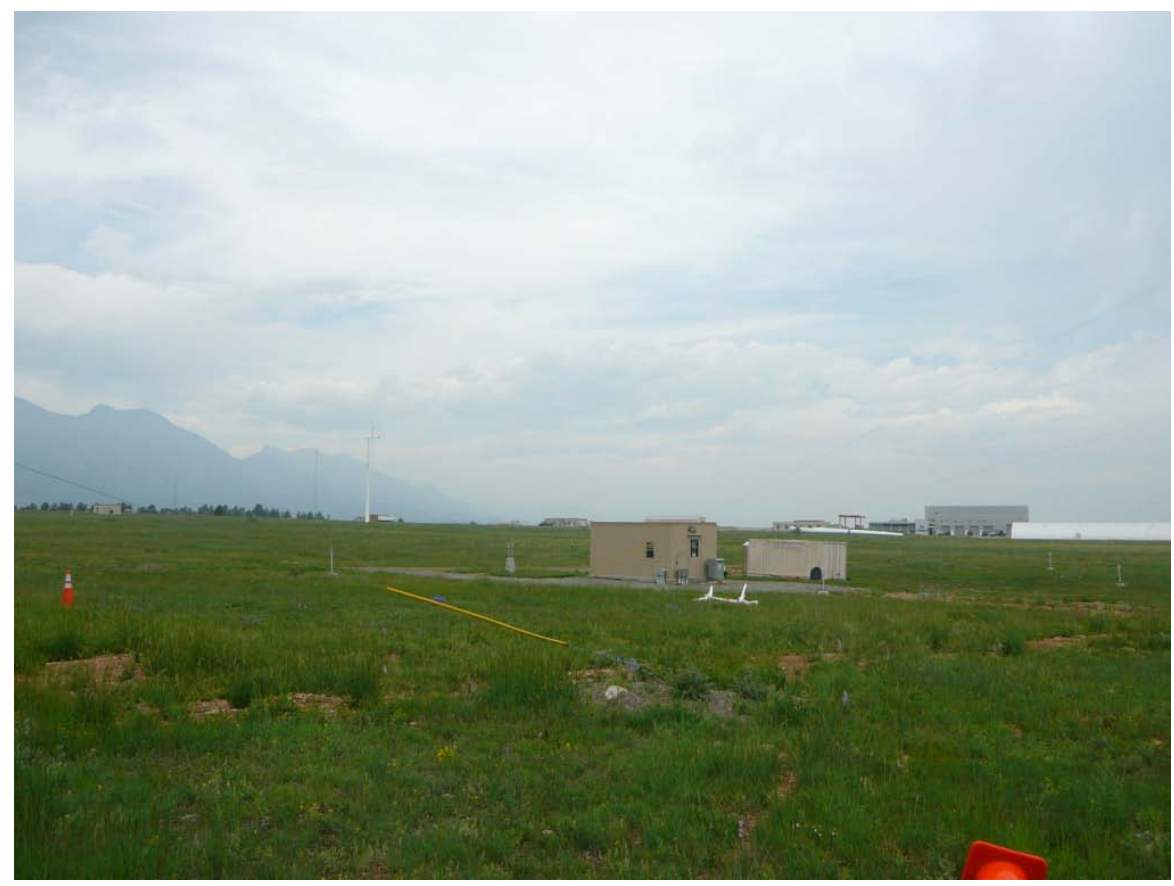

Figure A.7. West-northwest

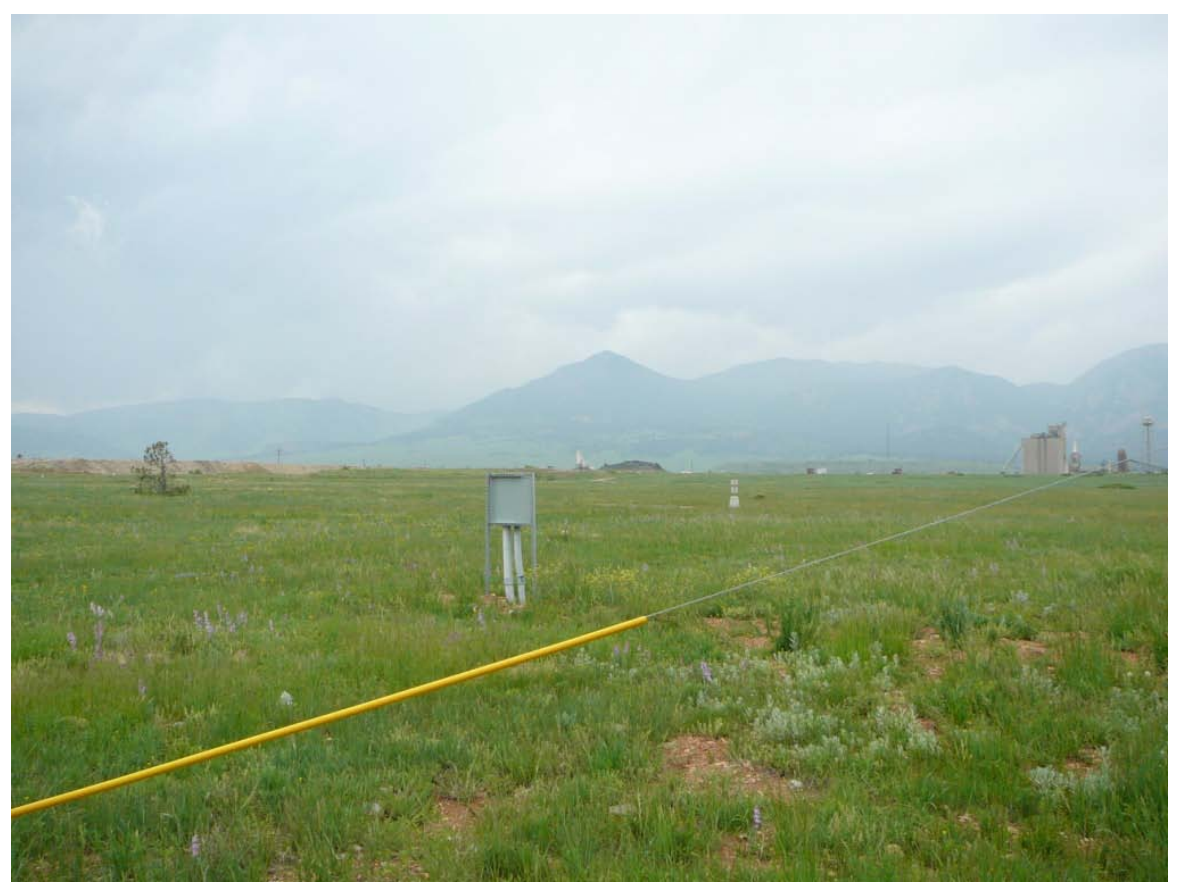

Figure A.8. West 
B. Appendix - Equipment Calibration Sheets 


\section{NREL METROLOGY LABORATORY}

\section{Test Report}

Test Instrument: Phaser powex Transducer \& 1-CT

$D O E$ \# $02825 \mathrm{C}$

Model \#

: Phaser-5-4A 20

$S / N ; 02061$

Calibration Date: $02 / 08 / 2008$

Due Date; $02 / 08 / 2010$

A. Set-Up for Total Real power Calibration:

A.1. Voltage is applied to phases $A \& N=100 \mathrm{~V}$ (a) $60 \mathrm{~Hz}$.

A.2. Current is applied to $n=10$-TURNS through the current transformer

that is connected to phases $A$.

A.3. Analog Output- 1 is measured across precision resistor $=250 \Omega$.

A.4. phaser Full Scale setting $=-1.5 \mathrm{KW}$ to $1.5 \mathrm{KW}$.

\begin{tabular}{|c|c|c|}
\hline $\begin{array}{c}\text { Input Current } \\
(A A C)\end{array}$ & $\begin{array}{l}\text { Input Power } \\
\qquad(K W)\end{array}$ & $\begin{array}{c}\text { Analog Output-1 } \\
\text { (VDC) }\end{array}$ \\
\hline 15 & 1.5 & 4.991 \\
\hline 10 & 1.0 & 4.328 \\
\hline 5 & 0.5 & 3.662 \\
\hline 0 & 0 & 2.995 \\
\hline-5 & -0.5 & 2.329 \\
\hline-10 & -1.0 & 1.663 \\
\hline-15 & -1.5 & 0.999 \\
\hline \multicolumn{3}{|c|}{$\begin{array}{l}\text { B. Set-Up for Power Factor Calibration: } \\
\text { B.1. Voltage \& Current are applied as A.1 \& A.2. } \\
\text { B.2. Analog Output-2 is measured across precision }\end{array}$} \\
\hline $\begin{array}{c}\text { Power } \\
(K W)\end{array}$ & Power Factor & $\begin{array}{l}\text { Analog Output }-2 \\
\text { (VDC) }\end{array}$ \\
\hline 1.5 & 1.0 & 4.988 \\
\hline " & 0.8 & 4.182 \\
\hline " & 0.6 & 3.382 \\
\hline " & 0.4 & 2.582 \\
\hline
\end{tabular}

Page 1 of 2

Figure B.1. Power transducer calibration sheet 


\section{NREL METROLOGY LABORATORY}

Test Report

Test Instrument: RTD probe

ModeI \#

: 78NO1NOONO4
DOE \#: 03506C

$S / N \quad: 0673553$

Due Date: $10 / 29 / 2008$

Calibration Date: 10/29/2007

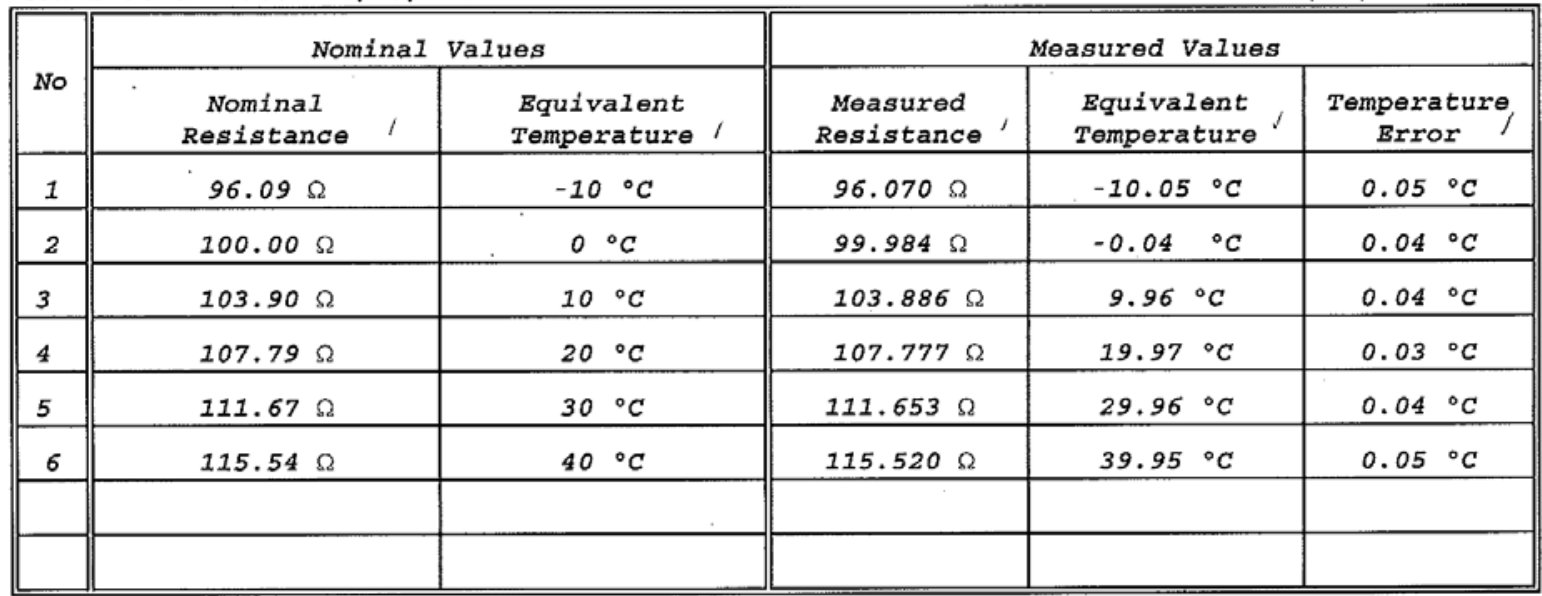

Notes:

1. Total Uncertainty of Nominal Values $= \pm 0.02{ }^{\circ} \mathrm{C}$

2. Calibration was performed at $23^{\circ} \mathrm{C}$ and $37 \% \mathrm{RH}$

3. Resistance is measured using 4-wire technique

Calibrated by: Reda

QA by: BeV

Date

: $10 / 29 / 2007$

Figure B.2. RTD probe calibration sheet I 
NREL METROLOGY LABORATORY

Test Report

Test Instrument: RTD-Probe

Model \#

Calibration Date: $10 / 10 / 2008$

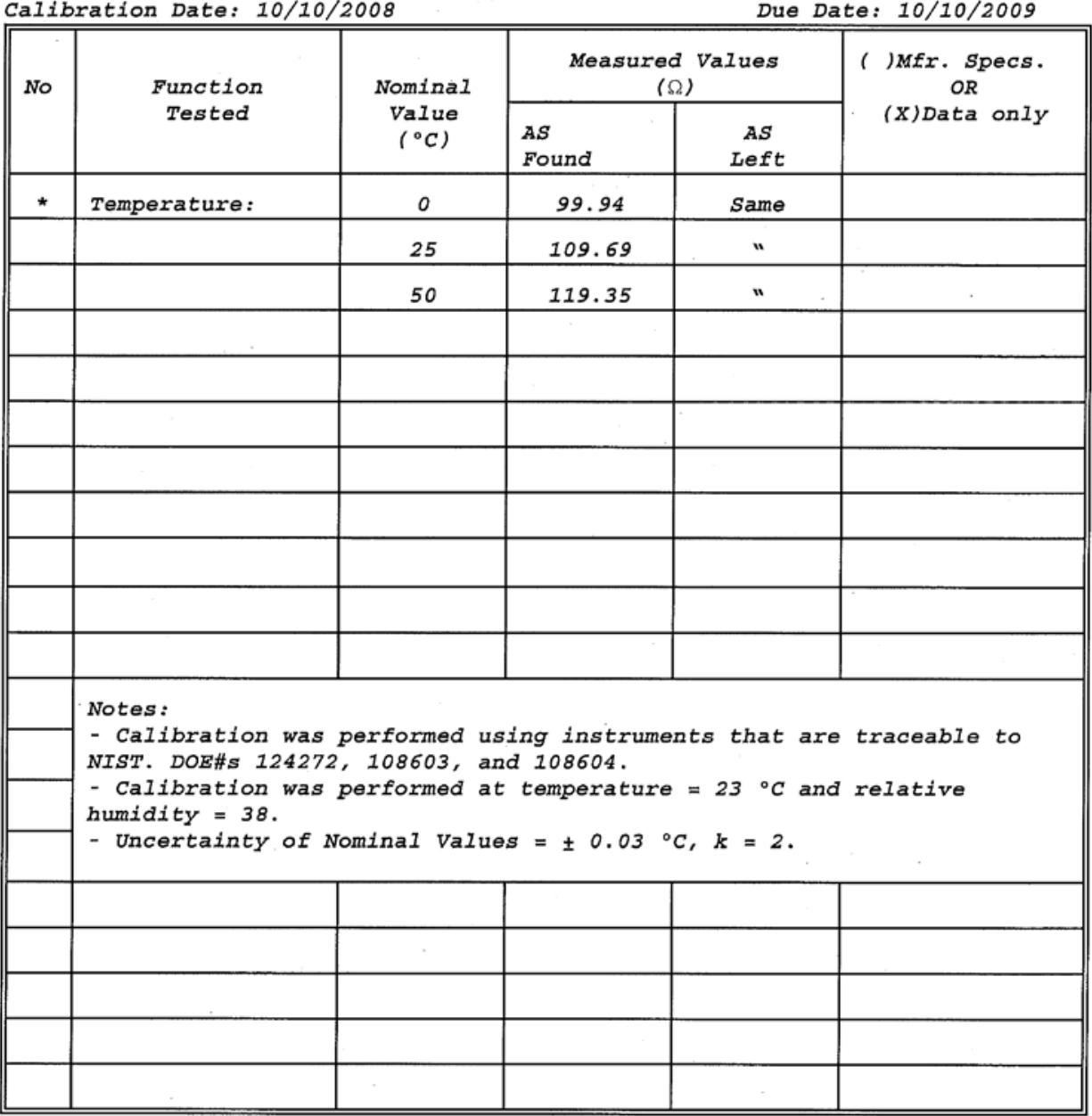

$D O E$ \# : $02746 C$

$S / N: 0602948$

Due Date: $10 / 10 / 2009$
OR 


\section{DEUTSCHER KALIBRIERDIENST DKD}

Kalibrierlaboratorium für Strömungsgeschwindigkeit von Luft Calibration laboratory for velocity of air flow

Akkreditiert durch die / accredited by the

Akkreditierungsstelle des DKD bei der

PHYSIKALISCH-TECHNISCHEN BUNDESANSTALT (PTB)

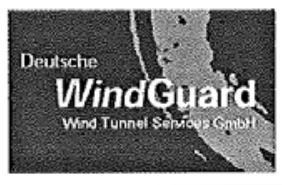
Deutsche WindGuard
Wind Tunnel Services $\mathrm{GmbH}$
Varel

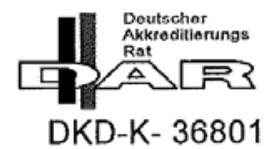

Kalibrierschein

Calibration Certificate

Kalibrierzeichen

DKD-K-

Calibration label

36801

07_2407

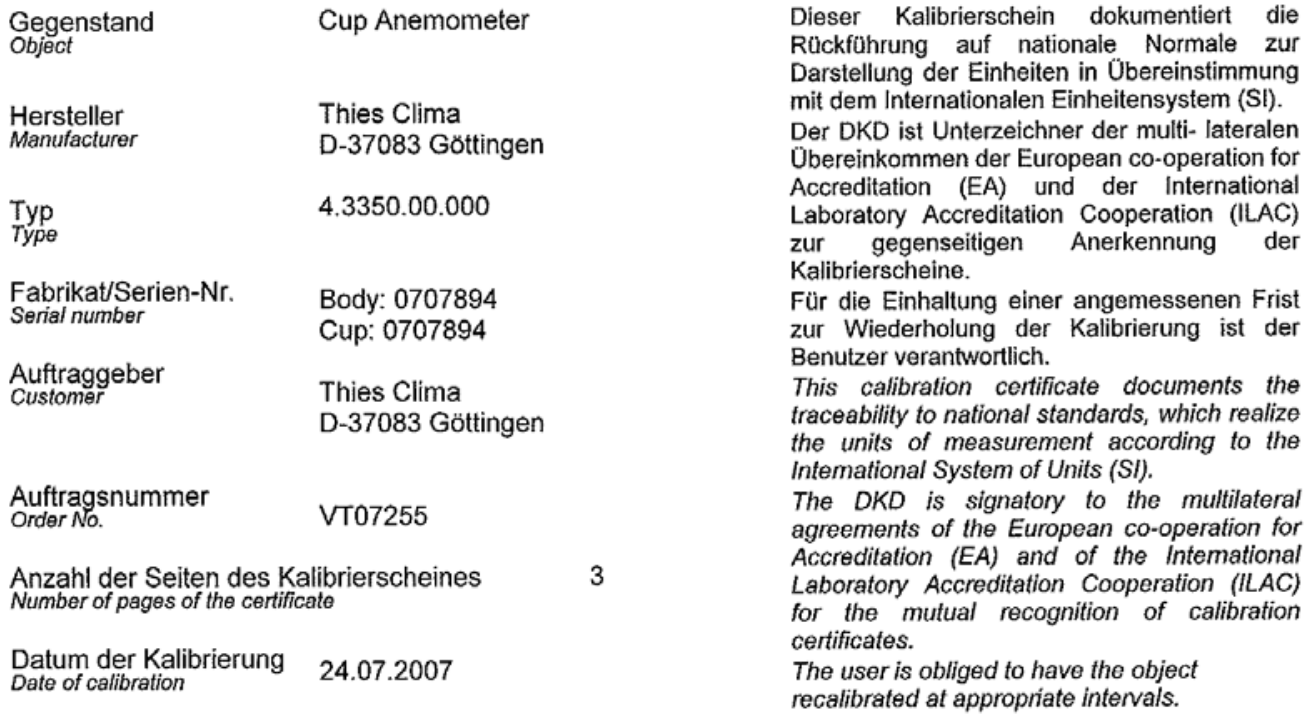

Dieser Kalibrierschein darf nur vollständig und unverändert weiterverbreitet werden. Auszüge oder Ånderungen bedürfen der Genehmigung sowohl der Akkreditierungsstelle des DKD als auch des ausstellenden Kalibrierlaboratoriums. Kalibrierscheine ohne Unterschrift und Stempel haben keine Gültigkeit.

This calibration certificate may not be reproduced other than in full except with the permission of both the Accreditation Body of the DKD and the issuing laboratory. Calibration certificates without signature and seal are not valid.

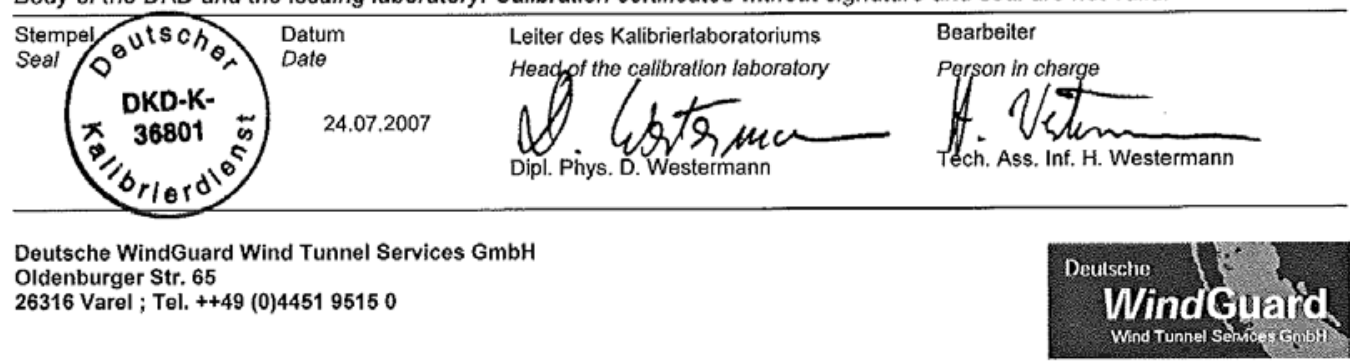

Figure B.4. Primary anemometer calibration sheet I 


\section{DEUTSCHER KALIBRIERDIENST DK⿴}

Kalibrierlaboratorium für Strömungsgeschwindigkeit von Luft

Calibration laboratory for velocity of air flow

Akkreditiert durch die / accredited by the

Akkreditierungsstelle des Deutschen Kalibrierdienstes

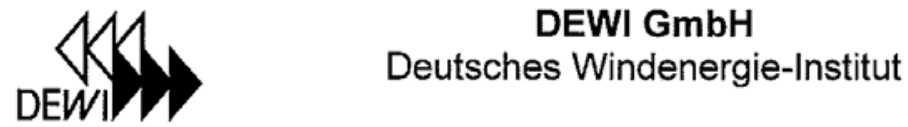

DEWI GmbH

DEWI

Deutsches Windenergie-Institut

\section{Kalibrierschein \\ Calibration certificate}

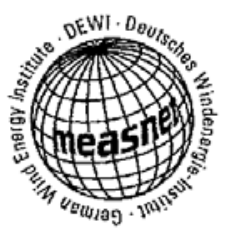

Cup Anemometer

Thies Clima

D-37083 Göttingen

4.3350 .00 .000

Typ

Type

Fabrikat/Serien-Nr.

Serial number

Auftraggeber

Customer

Auftragsnummer

Order No.

Anzahl der Seiten des Kalibrierscheines

Number of pages of the certificate

Datum der Kalibrierung

Date of calibration body: 0707894

cup: -

Thies Clima

D-37083 Goettingen,

AB0901617

$3+3$

16.06.09
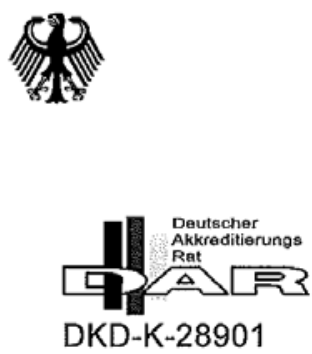

DKD-K-28901

Dieser Kalibrierschein darf nur vollständig und unverändert weiterverbreitet werden. Auszüge oder Ånderungen bedürfen der Genehmigung sowohl der Akkreditierungsstelle des DKD als auch des ausstellenden Kalibrierlaboratoriums. Kalibrierscheine ohne Unterschrift und Stempel haben keine Gültigkeit.

This calibration cerfificate may not be reproduced other than in full except with the permission of both the Accreditation Body of the DKD and the issuing laboratory. Calibration certificates without signature and seal are not valid.

$\begin{array}{ccc}\text { Datum } & \begin{array}{c}\text { Stellv. Leiter des Kalibrierlaboratoriums } \\ \text { Deputy head of the calibration laboratory }\end{array} \\ 28901 & \text { Date } & \text { Bearbeiter } \\ \text { Person in charge }\end{array}$

DEWI GmbH DEUTSCHES WINDENERGIE - INSTITUT

Ebertstr. 96, D-26382 Wilhelmshaven

Tel. $+49(0) 44214808-0$, Fax. $+49(0) 44214808-43$

Dieser Kalibrierschein dokumentiert die Rückführung auf nationale Normale zur einstimmung mit dem Internationalen Einheitensystem (SI).

Der DKD ist Unterzeichner der multilateralen Übereinkommen der European cooperation for Accreditation (EA) und der International Laboratory Accreditation Cooperation (ILAC) zur gegenseitigen Anerkennung der Kalibrierscheine.

Für die Einhaltung einer angemessenen Frist zur Wiederholung der Kalibrierung ist der Benutzer verantwortlich.

This calibration certificate documents the traceability to national standards, which realize the units of measurement according to the Intemational System of Units (SI).

The $D K D$ is signatory to the multilateral agreements of the European co-operation for Accreditation (EA) and of the Intemational Laboratory Accreditation Cooperation (ILAC) for the mutual recognition of calibration certificates.

The user is obliged to have the object The user is obliged to have the

Figure B.5. Primary anemometer calibration sheet II 


\section{Wind Vane Calibration Report}

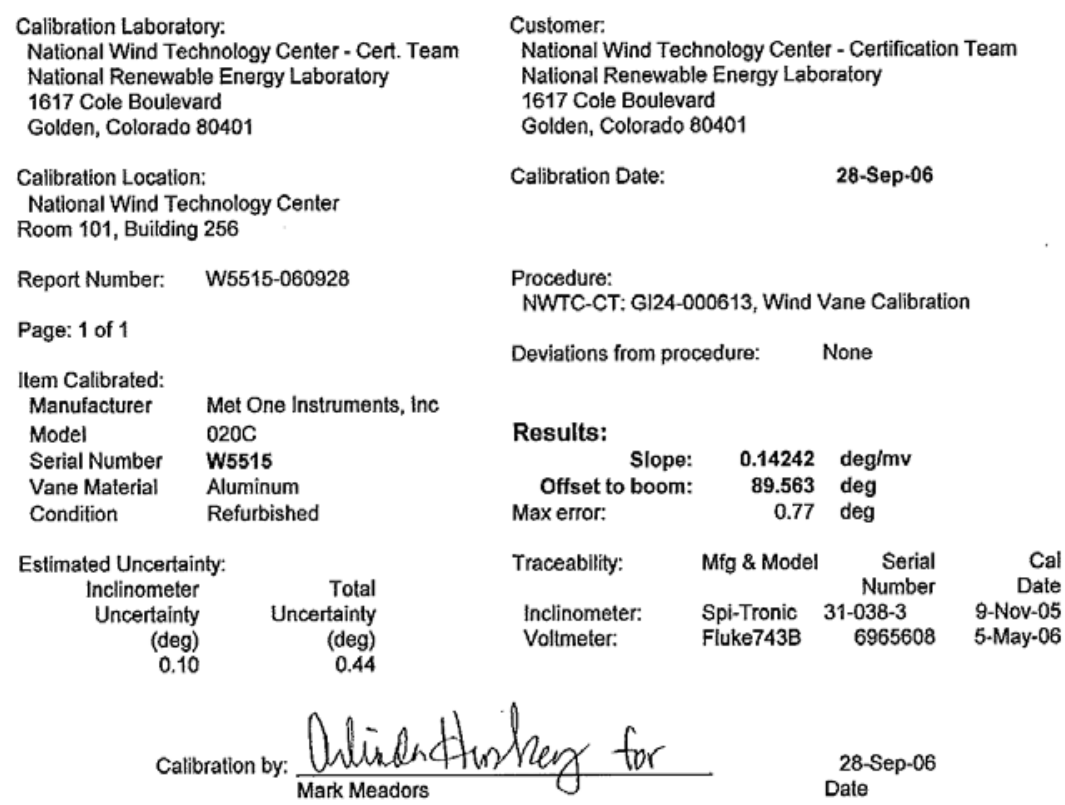

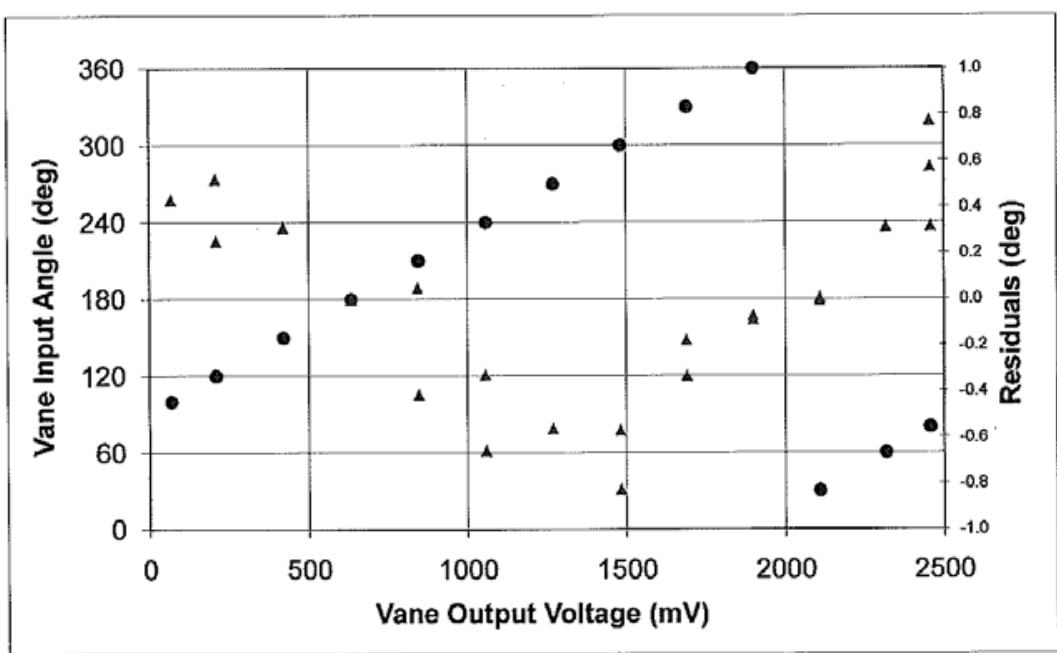

Figure B.6. Wind vane calibration sheet 


\section{NREL METROLOGY LABORATORY}

\section{Test Report}

Test Instrument: Pressure Transmitter

DOE \# : 03511C

Model *

: PTB101B

$S / N \quad: C 1040008$

Calibration Date: 09/09/2008

Due Date: 09/09/2009

\begin{tabular}{|c|c|c|c|c|}
\hline \multirow[t]{2}{*}{ No } & \multirow{2}{*}{$\begin{array}{l}\text { Function } \\
\text { Tested }\end{array}$} & \multirow{2}{*}{$\begin{array}{l}\text { Nominal } \\
\text { Value } \\
(k P a)\end{array}$} & $\begin{array}{l}\text { Measured Output Voltage } \\
\text { (VDC) }\end{array}$ & \multirow{2}{*}{$\begin{array}{c}\text { ( Mfr. Specs. } \\
\text { oR } \\
\text { (X)Data only } \\
\text { (mb) }\end{array}$} \\
\hline & & & As Found & \\
\hline \multirow[t]{2}{*}{ * } & Absolute Pressure & & & \\
\hline & . & 65 & 0.284 & \\
\hline . & & 70 & 0.558 & \\
\hline & & 75 & 0.829 & \\
\hline & & 80 & 1.102 & \\
\hline & & 85 & 1. 376 & \\
\hline & & 90 & 1.647 & \\
\hline & - & 95 & 1.919 & \\
\hline & & 100 & 2.192 & . \\
\hline & & 105 & 2.465 & \\
\hline & $\begin{array}{l}\text { Notes: } \\
\text { 1. Expanded Uncerta } \\
\text { 2. Calibration was } \\
\text { 3. Calibration was } \\
\text { numbers: } 02727 \mathrm{C} \text {, an }\end{array}$ & $\begin{array}{l}\text { ty of the } \\
\text { rformed at } \\
\text { rformed usi } \\
2301 \mathrm{C} \text {. }\end{array}$ & $\begin{array}{l}\text { I value is } \\
\text { and } 37 \% \text { RH. } \\
\text { andards tha }\end{array}$ & $\begin{array}{l}=2 . \\
\text { NIST. DOE }\end{array}$ \\
\hline & & & . & \\
\hline & & & & \\
\hline & & & & . \\
\hline & & & & \\
\hline
\end{tabular}

Figure B.7. Pressure transmitter calibration sheet 


\section{NREL METROLOGY LABORATORY}

Test Report

Test Instrument: Pressure Transmitter

$D O E$ \#: $03681 C$

Mode1 \#

: PTB101B

$S / N \quad: Y 3350027$

Calibration Date: 08/26/2008

Due Date: $08 / 26 / 2009$

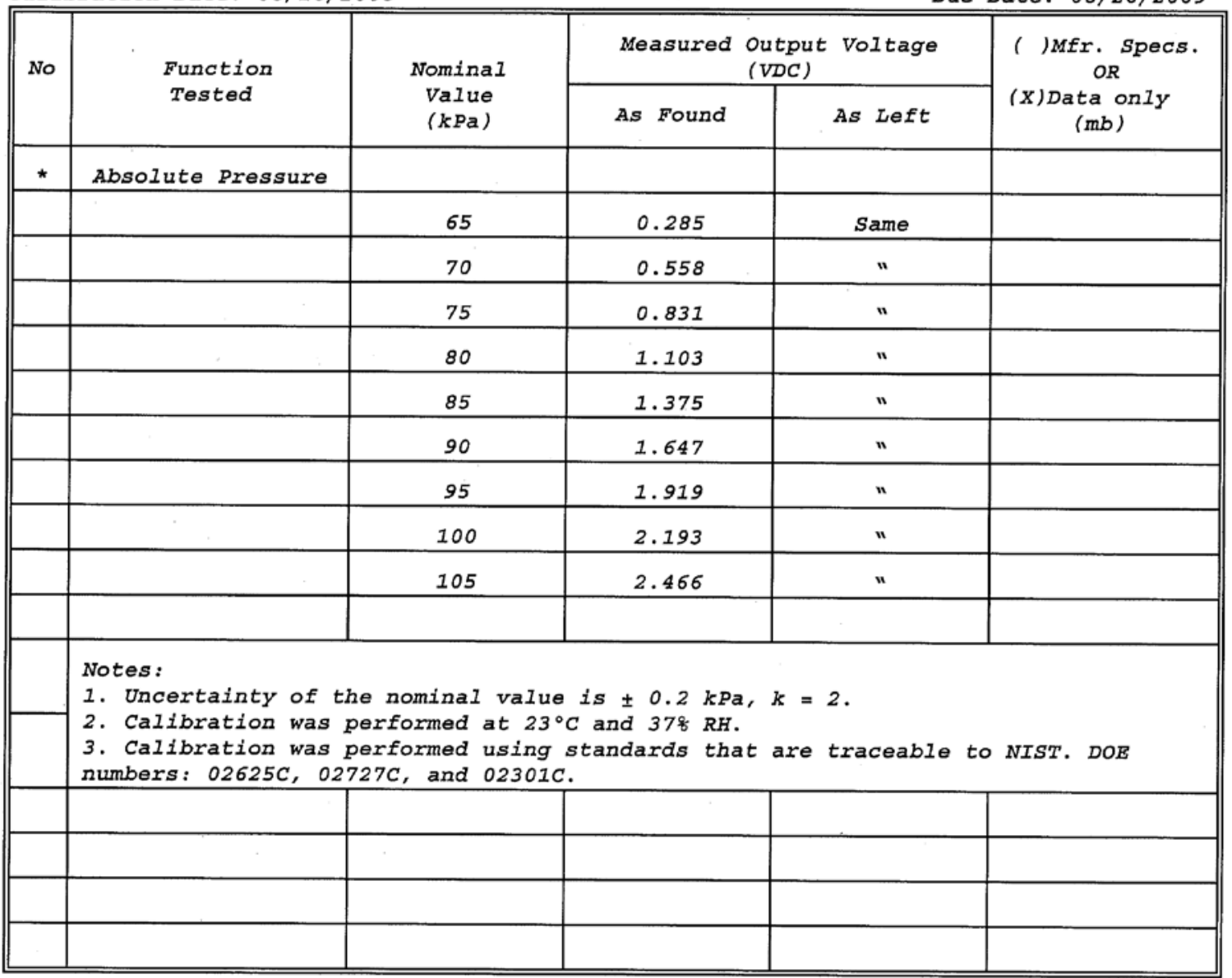

Figure B.8. Pressure transmitter calibration sheet II 


\section{Board Information:}

Serial Number: 12B6DD2

NI Part Number: 192580D-02

Description: NI 9229

Calibration Date: 28-JUN-07

Recommended Calibration Due Date: 28-JUN-08*

Ambient Temperature: $24^{\circ} \mathrm{C}$

Relative Humidity: $39 \%$
Certificate Information:

Certificate Number: 756395

Date Printed: 02-JUN-09

National Instruments certifies that at the time of manufacture, the above product was calibrated in accordance with applicable National Instruments procedures. These procedures are in compliance with relevant clauses of ISO 9001 and are designed to assure that the product listed above meets or exceeds National Instruments specifications.

National Instruments further certifies that the measurements standards and instruments used during the calibration of this product are traceable to National and/or International Standards administered by NIST or Euromet members or are derived from accepted values of natural physical constants.

The environment in which this product was calibrated is maintained within the operating specifications of the instrument and the standards.

The information shown on this certificate applies only to the instrument identified above and the certificate may not be reproduced, except in full, without prior written consent by National Instruments.

For questions or comments, please contact National Instruments Technical Support.

NI Hungary Software és

Hardware Gyártó Kft.

4031 Debrecen, Határ út

$1 / A$.

HUNGARY
Signed,

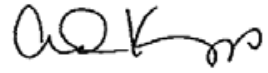

Andrew Krupp Vice President, Quality and Continuous Improvement

* Recommended calibration due date is based on a combination of calibration interval and, when applicable, calibration shelf life. This date may vary depending on your application requirements.

\section{Figure B.9. NI 9229 data acquisition module calibration sheet I}


Board Information:

Serial Number: 12BD192

NI Part Number: 192547D-01

Description: NI 9217

Calibration Date: 06-JUL-07

Recommended Calibration Due Date: 06-JUL-08*

Ambient Temperature: $23^{\circ} \mathrm{C}$

Relative Humidity: $43 \%$
Certificate Information:

Certificate Number: 762337

Date Printed: 02-JUN-09

National Instruments certifies that at the time of manufacture, the above product was calibrated in accordance with applicable National Instruments procedures. These procedures are in compliance with relevant clauses of ISO 9001 and are designed to assure that the product listed above meets or exceeds National Instruments specifications.

National Instruments further certifies that the measurements standards and instruments used during the calibration of this product are traceable to National and/or International Standards administered by NIST or Euromet members or are derived from accepted values of natural physical constants.

The environment in which this product was calibrated is maintained within the operating specifications of the instrument and the standards.

The information shown on this certificate applies only to the instrument identified above and the certificate may not be reproduced, except in full, without prior written consent by National Instruments.

For questions or comments, please contact National Instruments Technical Support.

NI Hungary Software és

Hardware Gyártó Kft.

4031 Debrecen, Határ út

$1 / A$.

HUNGARY
Signed,

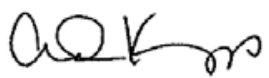

Andrew Krupp

Vice President, Quality and Continuous Improvement

* Recommended calibration due date is based on a combination of calibration interval and, when applicable, calibration shelf life. This date may vary depending on your application requirements.

\section{Figure B.10. NI 9217 data acquisition module calibration sheet I}


Board Information:

Serial Number: 12E9C3E

NI Part Number: 193299F-01

Description: NI-9205

Calibration Date: 08-OCT-07

Recommended Calibration Due Date: 08-OCT-08*

Ambient Temperature: $22^{\circ} \mathrm{C}$

Relative Humidity: $39 \%$
Certificate Information:

Certificate Number: 834976

Date Printed: 02-JUN-09

National Instruments certifies that at the time of manufacture, the above product was calibrated in accordance with applicable National Instruments procedures. These procedures are in compliance with relevant clauses of ISO 9001 and are designed to assure that the product listed above meets or exceeds National Instruments specifications.

National Instruments further certifies that the measurements standards and instruments used during the calibration of this product are traceable to National and/or International Standards administered by NIST or Euromet members or are derived from accepted values of natural physical constants.

The environment in which this product was calibrated is maintained within the operating specifications of the instrument and the standards.

The information shown on this certificate applies only to the instrument identified above and the certificate may not be reproduced, except in full, without prior written consent by National Instruments.

For questions or comments, please contact National Instruments Technical Support.

NI Hungary Software és

Hardware Gyártó Kft.

4031 Debrecen, Határ út

$1 / A$.

HUNGARY
Signed,

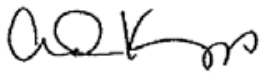

Andrew Krupp

Vice President, Quality and Continuous Improvement

* Recommended calibration due date is based on a combination of calibration interval and, when applicable, calibration shelf life. This date may vary depending on your application requirements.

Figure B.11. NI 9205 data acquisition module calibration sheet I 


\section{Davis|Calibration}

Company ID: 229037

NATIONAL INSTRUMENTS

11500 N. MOPAC EXPWY

ATTN. RMA DEPT.

AUSTIN, TX 78759

Instrument ID: 12B6DD2

Manufacturer. NATIONAL INSTRUMENTS

Description: 4-CHANNEL, $\pm 60 \mathrm{~V}$, 24-BIT SIMULTANEOUS ANALOG INPUT

Instrument Identification

\section{Certificate of Calibration}

3214335

Certificate Page 1 of 1

PO Number: 337683

Accuracy: Mfr Specifications

Certificate Information

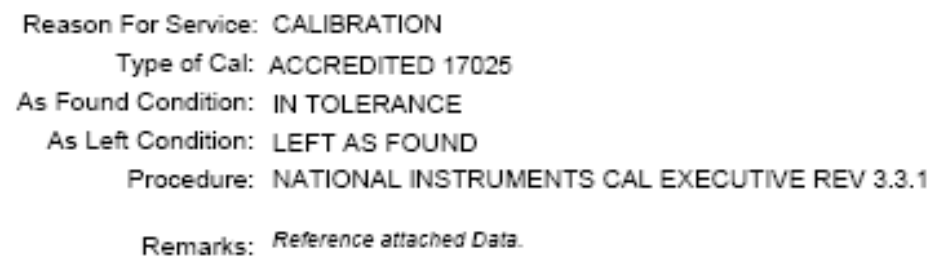

Model Number: NI 9229

Serial Number: 12B6DD2

Remark: Reterce attoched Date

\author{
Technician: WAYNE GETCHELL \\ Cal Date 06May2009 \\ Cal Due Date: 06May2010 \\ Interval: 12 MONTHS \\ Temperature: $23.0 \mathrm{C}$ \\ Humidity: $44.0 \%$
}

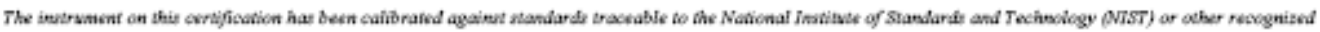

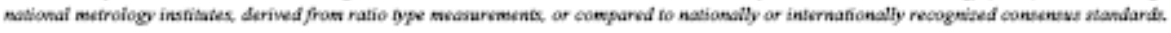

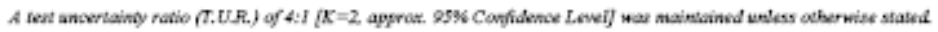

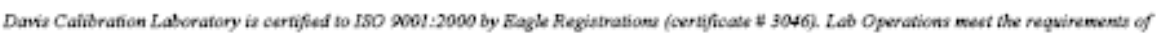

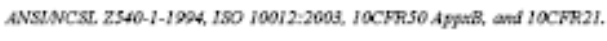

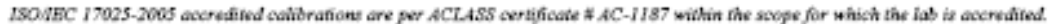

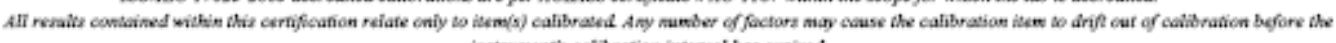
instramenr's caî̉ ration interval has expired.

This cerlificate shall not be reproduced except in fall, without writen comsent of Dewis Calibration Laboratory.
\end{abstract}

Approved By: VICTOR PENA

Service Representative

Calibration Standards

$\frac{\text { NIST Traceable\# }}{3143038} \frac{\text { Inst. ID\# }}{15-0271} \quad \frac{\text { Description }}{\text { MULTIFUNCTION CALIBRATOR }} \quad \frac{\text { Model }}{5700 A} \quad \frac{\text { Cal Date }}{15 A p r 2009} \frac{\text { Date Due }}{14 J u 12009}$

Figure B.12. NI 9229 data acquisition module calibration sheet II 


\section{Davis|Calibration}

Company ID: 229037

NATIONAL INSTRUMENTS

11500 N. MOPAC EXPWY

ATTN. RMA DEPT.

AUSTIN, TX 78759

Instrument ID: 12BD192

Manufacturer: NATIONAL INSTRUMENTS

Description: 4-CH 100 OHM 24-BIT RTD ANALOG INPUT

Accuracy: Mfr. Specifications

\section{Certificate of Calibration}

3214168

Certificate Page 1 of 1

Instrument Identification

\author{
PO Number: 337683
}

Model Number: NI 9217

Serial Number: 12BD192

\section{Certificate Information}

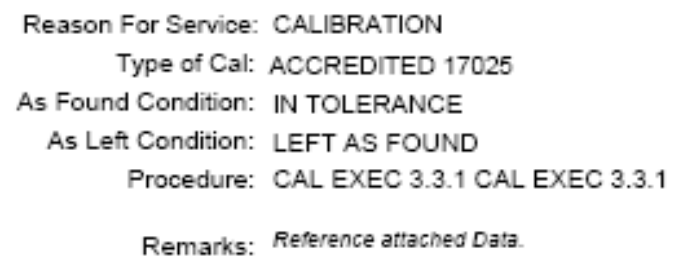

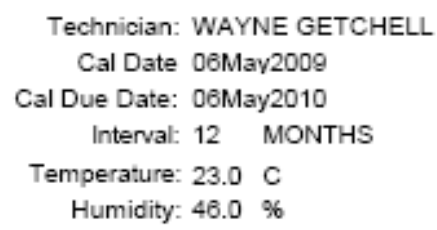

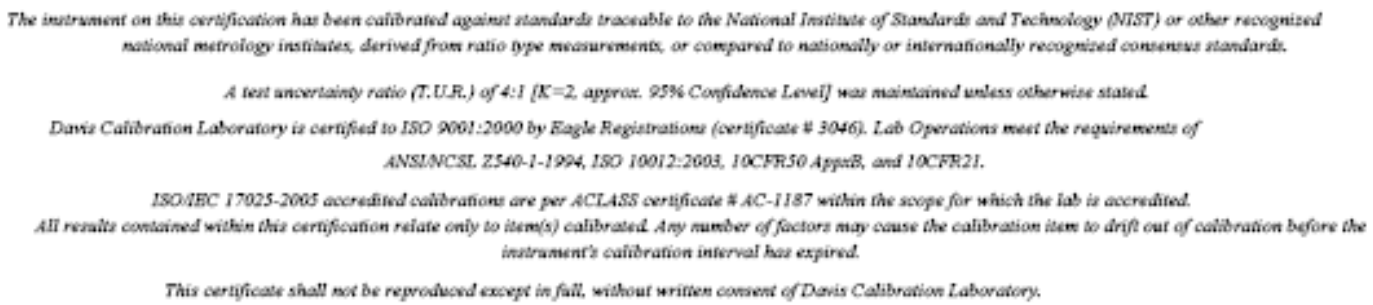

This certificats shall wo be reproducd except in fall, without wrimen consent of Dowis Catibration Laboratory.

\section{Approved By: VICTOR PENA}

Service Representative

\section{Calibration Standards}

\begin{tabular}{|c|c|c|c|c|c|}
\hline NIST Traceable\# & Inst. ID\# & Description & Model & Cal Date & Date Due \\
\hline 3078982 & $15-0011$ & DECADE RESISTOR & DB52 & $24 \mathrm{Mar} 2009$ & $24 \mathrm{Mar} 2010$ \\
\hline 3004176 & $15 \cdot 0060$ & DIGITAL MULTIMETER (GOLDEN CAL) & 3458A OPT 002 & 17Feb2009 & 17May2009 \\
\hline
\end{tabular}

Figure B.13. NI 9217 data acquisition module calibration sheet II 
Davis|Calibration

Company ID: 229037

NATIONAL INSTRUMENTS

11500 N. MOPAC EXPWY

ATTN. RMA DEPT.

AUSTIN, TX 78759

Instrument ID: 12E9C3E

Manufacturer: NATIONAL INSTRUMENTS

Description: $32-\mathrm{CH} \pm 200 \mathrm{MV}$ TO $\pm 10 \mathrm{~V}, 16-\mathrm{BIT}, 250 \mathrm{KS} / \mathrm{S}$ ANALOG INPUT MODULE

Instrument Identification

PO Number: 337883
Certificate of Calibration

3214141

Certificate Page 1 of 1

Accuracy: Mfr Specifications

Certificate Information

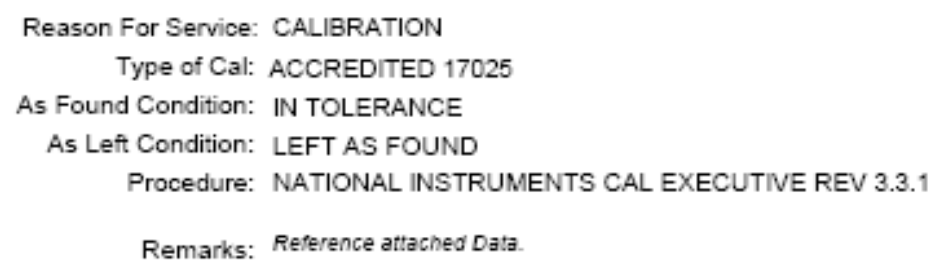

.

Remarks: Reterice atacheg

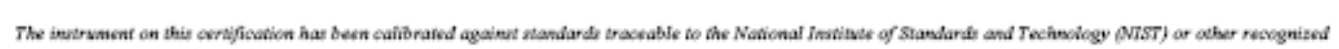

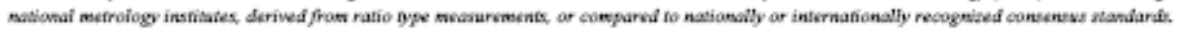

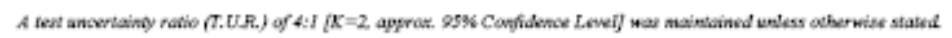

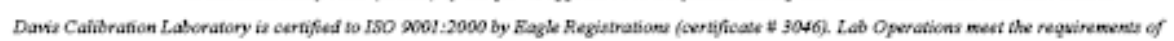

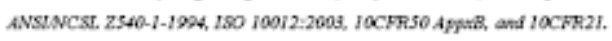

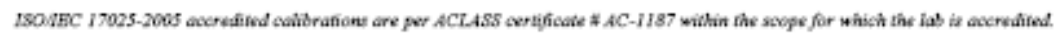

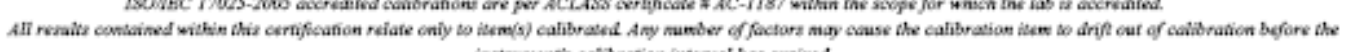

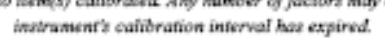

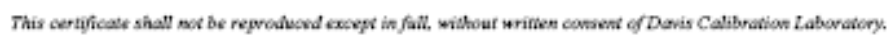

Approved By: VICTOR PENA

Service Representative

\section{Calibration Standards}

$\frac{\text { NIST Traceable\# }}{3143038} \frac{\text { Inst. ID\# }}{15-0271} \quad \frac{\text { Description }}{\text { MULTIFUNCTION CALIBRATOR }} \quad \frac{\text { Model }}{5700 \mathrm{~A}} \quad \frac{\text { Cal Date }}{15 A p r 2009} \frac{\text { Date Due }}{14 J u 12009}$

Davis Calibration - 2324 Ridgepoint Drive, Suite D - Austin, TX 78754 - Phone: 800-365-0147 • Fax: 512-926-8450

Figure B.14. NI 9205 data acquisition module calibration sheet II 


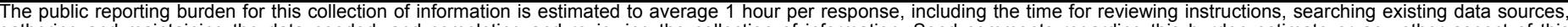

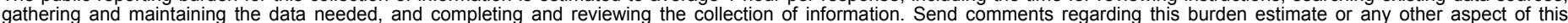

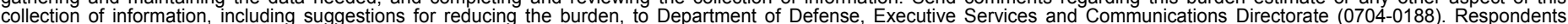

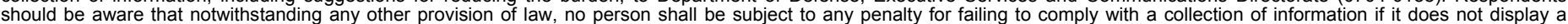

should be aware that notwithstanding

PLEASE DO NOT RETURN YOUR FORM TO THE ABOVE ORGANIZATION.
1. REPORT DATE (DD-MM-YYYY)
December 2009
4. TITLE AND SUBTITLE
Wind Turbine Generator System Power Performance Test Report
for the Mariah Windspire 1-kW Wind Turbine

3. DATES COVERED (From - To)

5a. CONTRACT NUMBER

DE-AC36-08-GO28308

5b. GRANT NUMBER

5c. PROGRAM ELEMENT NUMBER

5d. PROJECT NUMBER

NREL/TP-500-46192

5e. TASK NUMBER

WE102211

5f. WORK UNIT NUMBER
7. PERFORMING ORGANIZATION NAME(S) AND ADDRESS(ES)

National Renewable Energy Laboratory

1617 Cole Blvd.

Golden, CO 80401-3393
8. PERFORMING ORGANIZATION REPORT NUMBER

NREL/TP-500-46192

9. SPONSORING/MONITORING AGENCY NAME(S) AND ADDRESS(ES)

10. SPONSOR/MONITOR'S ACRONYM(S)

NREL

11. SPONSORING/MONITORING AGENCY REPORT NUMBER

12. DISTRIBUTION AVAILABILITY STATEMENT

National Technical Information Service

U.S. Department of Commerce

5285 Port Royal Road

Springfield, VA 22161

13. SUPPLEMENTARY NOTES

14. ABSTRACT (Maximum 200 Words)

This report summarizes the results of a power performance test that NREL conducted on the Mariah Windspire 1-kW wind turbine. During this test, two configurations were tested on the same turbine. In the first configuration, the turbine inverter was optimized for power production. In the second configuration, the turbine inverter was set for normal power production. In both configurations, the inverter experienced failures and the tests were not finished.

\section{SUBJECT TERMS}

wind energy; Mariah; Mariah Windspire 1-kW wind turbine; 1-kW wind turbine; power performance

\begin{tabular}{|c|c|c|}
\hline \multicolumn{3}{|c|}{ 16. SECURITY CLASSIFICATION OF: } \\
\hline $\begin{array}{l}\text { a. REPORT } \\
\text { Unclassified }\end{array}$ & $\begin{array}{l}\text { b. ABSTRACT } \\
\text { Unclassified }\end{array}$ & $\begin{array}{l}\text { c. THIS PAGE } \\
\text { Unclassified }\end{array}$ \\
\hline
\end{tabular}

\begin{tabular}{|c|c|} 
17. LIMITATION & 18. \\
OF ABSTRACT & OF PAGES \\
UL &
\end{tabular}

19a. NAME OF RESPONSIBLE PERSON

19b. TELEPHONE NUMBER (Include area code) 